\title{
A FISCAL INCIDENCE ANALYSIS FOR ETHIOPIA
}

Ruth Hill, Gabriela Inchauste, Nora Lustig, Eyasu Tsebaye, and Tassew Woldebanna

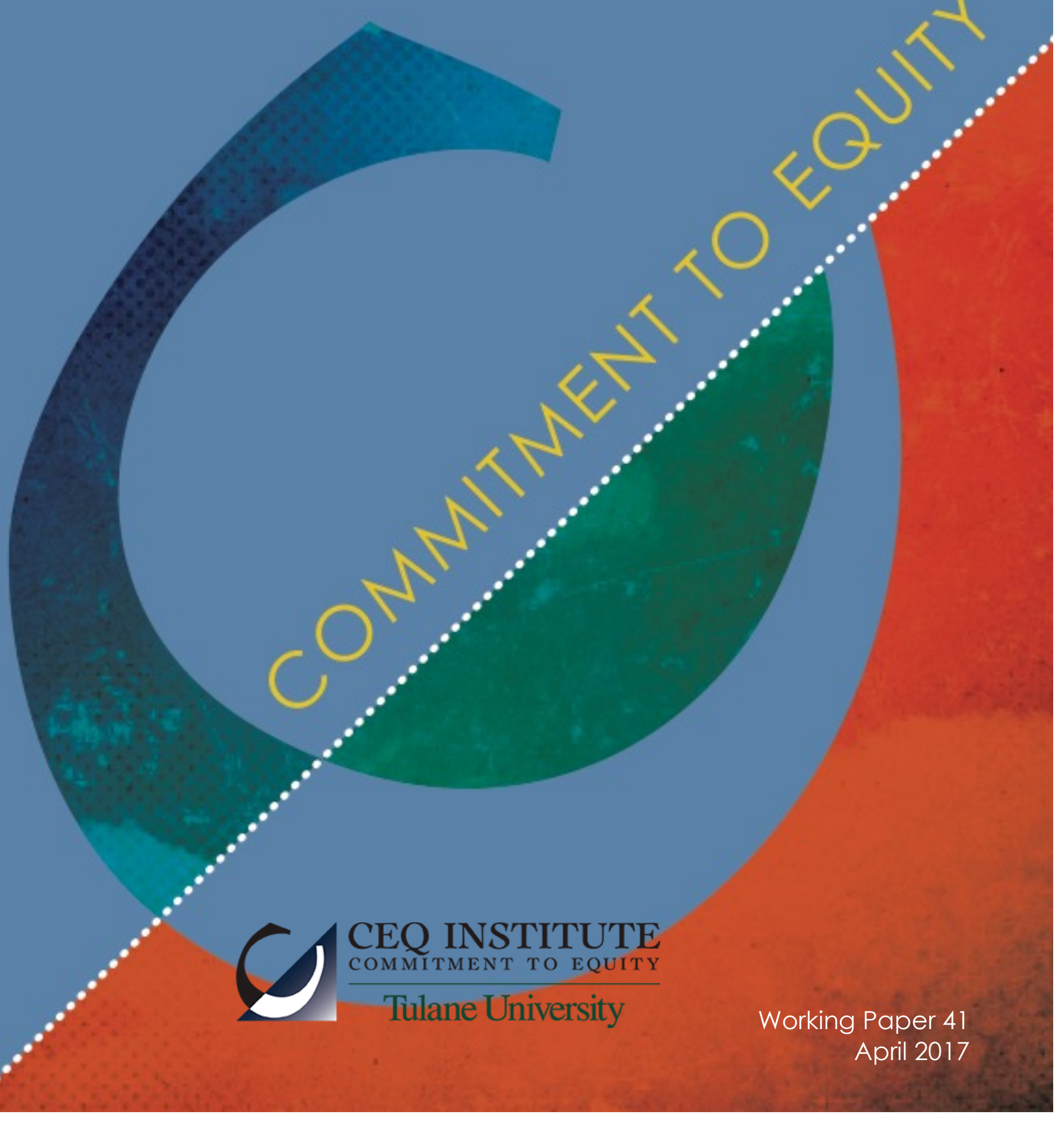




\section{The CEQ Working Paper Series}

The CEQ Institute at Tulane University works to reduce inequality and poverty through rigorous tax and benefit incidence analysis and active engagement with the policy community. The studies published in the CEQ Working Paper series are pre-publication versions of peer-reviewed or scholarly articles, book chapters, and reports produced by the Institute. The papers mainly include empirical studies based on the CEQ methodology and theoretical analysis of the impact of fiscal policy on poverty and inequality. The content of the papers published in this series is entirely the responsibility of the author or authors. Although all the results of empirical studies are reviewed according to the protocol of quality control established by the CEQ Institute, the papers are not subject to a formal arbitration process. The CEQ Working Paper series is possible thanks to the generous support of the Bill \& Melinda Gates Foundation. For more information, visit www.commitmentoequity.org.

The CEQ logo is a stylized graphical representation of a Lorenz curve for a fairly unequal distribution of income (the bottom part

of the $\mathrm{C}$, below the diagonal) and a concentration curve for a very progressive transfer (the top part of the $\mathrm{C}$ ). 
$\mathscr{C}$

CEQ INSTITUTE

COMMITMENT TO EQUITY

Tulane University

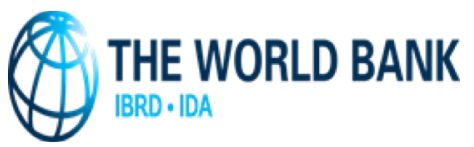

\section{A FISCAL INCIDENCE ANALYSIS FOR ETHIOPIA.}

\author{
Ruth Hill, Gabriela Inchauste, Nora Lustig, Eyasu Tsebaye, and Tassew \\ Woldehanna $^{+}$
}

CEQ Working Paper 41

APRIL 2017

\begin{abstract}
This paper uses the 2010/11 Household Consumption Expenditure Survey (HCES) and the Welfare Monitoring Survey (WMS) collected by the Central Statistical Agency (CSA) of Ethiopia, as well as 2011 data from national income and public finance accounts from the Ministry of Finance and Development to assess the effects of government taxes, transfers and social spending on the distribution of income in Ethiopia, and examines whether policy can be modified to improve the well-being of the poor. This study finds that fiscal policy in Ethiopia is progressive and equalizing, and poor populations are net beneficiaries of the fiscal system. Though the depth and severity of poverty is ameliorated, the poverty headcount is higher after taxes, transfers, and subsidies. Though Ethiopia's Gini coefficient was lowered by 2 points, the poverty headcount (under $\$ 1.25$ USD per day in 2005 PPP) is increased from $31.9 \%$ to $32.4 \%$ as a result of fiscal policy. Direct taxes, such as PIT, were progressive and equalizing, but aggregately poverty-increasing due to a low cutoff income for PIT and a regressive land use fee. Direct transfers, especially the Productive Safety Net Program (PSNP), were progressive, equalizing, and poverty-reducing. Indirect taxes were progressive and equalizing, but poverty-increasing. Subsidies for goods like kerosene were relatively equalizing, while electricity subsidies were regressive because poor households often do not use electricity. Expenditures on primary education and health were progressive and equalizing, but spending on tertiary education was not. Due to low completion rates of primary education amongst the poor, access to tertiary education by the poor is almost nil.
\end{abstract}

Keywords: fiscal incidence, taxation, social spending, inequality, poverty, Ethiopia

JEL Codes: H22, D31, I38

\footnotetext{
'This paper was published as a chapter of The Distributional Impact of Fiscal Policy: Evidence from Developing Countries, edited by Gabriela Inchauste and Nora Lustig, World Bank, 2017. This study has been produced by the Commitment to Equity (CEQ) Institute and possible thanks to the generous support from the Bill \& Melinda Gates Foundation. Launched in 2008, the CEQ project is an initiative of the Center for Inter-American Policy and Research (CIPR) and the department of Economics, Tulane University, the Center for Global Development and the Inter-American Dialogue. The CEQ project is housed in the Commitment to Equity Institute at Tulane. For more details visit www.commitmentoequity.org.

${ }^{\dagger}$ Ruth Hill is Senior Economist, Poverty \& Equity Global Practice at the World Bank; Gabriela Inchauste is Lead Economist, Poverty \& Equity Global Practice at the World Bank; Nora Lustig is the Samuel Z. Srone Professor of Latin American Economics and Director of the Commitment to Equity Institute at Tulane University. She is also a Nonresident Fellow at the Center for Global Development and Inter-American Dialogue; Esayu Tsehaye is an Economist, Poverty \& Equity Global Practice at the World Bank; Tassew Woldehanna is Professor of Economics and Vice President for Research and Technology Transfer at Addis Ababa University.
} 


\section{Introduction}

Ethiopia has an impressive record of equitable growth. Since the early 1990s, the country has pursued a "developmental state" model with high public sector investment to encourage growth and improve access to basic services. Indeed, strong economic growth ${ }^{1}$ and improved public services have been the primary drivers of poverty reduction over the past decade (World Bank 2015). Ethiopia has not only reduced poverty significantly-from 45.5 percent in 1995/96 to 29.6 percent in 2010/11 — but also has maintained low inequality. With a 2011 Gini coefficient of 0.302 (for per capita expenditures), Ethiopia remains one of the less-unequal countries in the developing world.

Despite this progress, the poorest have not fared well in recent years. Although the incidence of poverty continued to fall in Ethiopia between 2005 and 2011, the depth of poverty did not fall, and the poverty severity index increased (World Bank 2015). ${ }^{2}$ Even as the government's commitment to poverty reduction remains strong, the challenges have grown. In particular, with a consolidated primary fiscal deficit at about 4.5 percent of gross domestic product (GDP) in 2013 and a growing debt burden, fiscal space to expand social spending has become more limited. Despite Ethiopia's progress, it remains one of the world's poorest countries. ${ }^{4}$ In such an environment, the question becomes whether the government is making the best possible use of fiscal policy to achieve its goal of reducing poverty, both in the present and in the long-term.

In this context, this paper assesses the impact of fiscal policy on the incidence, depth, and severity of poverty and examines whether there is room for an increased role for fiscal policy in improving the well-being of the very poorest. Our analysis has three unique features:

- It is the first comprehensive analysis of the impact of fiscal policy on inequality and poverty in Ethiopia.

\footnotetext{
${ }^{1}$ Economic growth averaged 10 percent a year between 2007 and 2015 was much higher compared to the average in Sub-Saharan Africa (4.6 percent) and low-income countries (5.4 percent) (World Development Indicators database).

${ }^{2}$ While poverty incidence refers to the basic poverty headcount (percentage of the population that is poor), the depth of poverty (also called the "poverty gap") is the average percentage by which individuals fall below the poverty line. The poverty severity index (also called "poverty intensity") is calculated as the poverty gap index squared; it implicitly gives greater weight to the poorest individuals, making it a combined measure of poverty and income inequality. These three poverty metrics are known as the Foster-Greer-Thorbecke (FGT) indexes (Foster, Greer, and Thorbecke 1984).

${ }^{3}$ Ethiopia's first and second Growth and Transformation Plans, for instance, have aimed at sustaining rapid, broad, and equitable economic growth as well as achieving the United Nations Millennium Development Goals (MoFED 2010; NPC 2016). The longer-term objectives are to eradicate poverty, bring about structural transformation of the economy, and reach lower-middle-income status by 2030 .

${ }^{4}$ Ethiopia's 2015 per capita gross national income of US $\$ 590$ (using the World Bank's Atlas conversion method) is substantially lower than the 2015 average for Sub-Saharan Africa of US\$1,628 (World Bank data, http://data.worldbank.org/?locations=ET-ZG).
} 
- It assesses the contribution of each fiscal instrument to the reduction in inequality and poverty.

- Because it applies the Commitment to Equity (CEQ) methodology (Lustig and Higgins 2013; Lustig, forthcoming) to analyze the distributional impact of fiscal policy in a holistic and standardized way, one can compare Ethiopia with other countries to which the CEQ methodology has been applied. ${ }^{5}$

The analysis uses the 2010/11 Household Consumption Expenditure Survey (HCES) and Welfare Monitoring Survey (WMS) collected by the Central Statistical Agency (CSA) of Ethiopia as well as 2011 data from national income and public finance accounts from the Ministry of Finance and Economic Development (now called the Ministry of Finance and Economic Cooperation). In terms of the coverage of fiscal policy components, the analysis includes 83 percent of tax revenue but can only capture 33 percent of government spending even though all government spending on direct transfers and consumption subsidies is included. This is important to keep in mind, as described below.

A tax or expenditure instrument could theoretically be progressive but not have large impacts on equity if it is too small, as further discussed in Inchauste and Lustig (2017) (also see Duclos and Tabi 1996). More interestingly, a tax could be regressive but still equalizing if analyzed in conjunction with other taxes and, especially, transfers. ${ }^{6}$ This point is especially important, because a regressive tax could actually end up helping redistribution if it is used to finance highly progressive expenditures. Furthermore, taxes and transfers could be equalizing and yet poverty-increasing because inequality depends on relative incomes while poverty is affected by absolute incomes: that is, a tax system could be progressive and equalizing but hurt the poor if they pay more in taxes than they receive through transfers (Higgins and Lustig 2016). With this in mind, the fiscal incidence analysis of Ethiopia yields three main results:

- The tax and social spending system is equalizing overall. Taxes make up a larger percent of income for wealthier households, and direct transfers are targeted primarily to poorer households. Although subsidies are not always progressive, social spending in general is progressive.

- Taxes and transfers are progressive, and given their size, they help to reduce income inequality and also reduce both the depth and the severity of poverty.

- Despite the progressivity of taxes and spending, because incomes are so low, some households are impoverished as a result of fiscal policy. The analysis finds that poor households pay both direct and indirect taxes, but the transfers and benefits they receive

\footnotetext{
${ }^{5}$ For more details about the CEQ framework, see Inchauste and Lustig (2017) and the CEQ Institute website: http://www.commitmentoequity.org.

${ }^{6}$ As soon as there is more than one intervention, assessing the progressivity of fiscal interventions individually is not sufficient to determine whether they are equalizing (see, for example, Lambert 2002, 277-78). For a full explanation, see Lustig (2018).
} 
do not compensate all households for the taxes they have paid. As a result, 1 in 4 of all households are impoverished (either made poor or poorer) after direct taxes are paid and direct transfers received, and nearly 1 in 10 of all households are impoverished when all taxes paid and benefits received (including public spending on education and health) are taken into account.

The analysis highlights two ways in which this negative impact could be reduced: (a) by reducing the incidence of direct tax on the bottom deciles and increasing the progressivity of direct taxes, particularly personal income tax and agricultural taxes; and (b) by redirecting spending on subsidies to spending on direct transfers to the poorest.

In considering only the redistributive effects of fiscal policy, as Inchauste and Lustig (2017) further explains, this analysis does not offer conclusions about whether specific taxes or expenditures are desirable. Redistribution is only one relevant criterion in developing good tax or spending policies. The results of this paper are but one input to public policy making, one to be weighed with other evidence before deciding whether a tax or expenditure is desirable.

Moreover, some of the expenditure items analyzed here have important long-run impacts beyond the short-term distributional impacts. For example, education spending could be seen not only as an investment in individuals' opportunities to earn higher future incomes, but also more generally as an investment in the country's productivity as a whole. To the extent that the analysis presented here cannot capture the long-run distributional impact of spending on infrastructure and other public goods, the analysis should be interpreted simply as a picture in time, as the approach is unable to inform the trade-off between current transfers and the longrun impacts of investment in physical and human capital.

The rest of the paper is organized as follows: The next section describes the structure of taxes and spending in Ethiopia. The "Data Sources and Assumptions" section details the data used and assumptions made in estimating the taxes paid by households and the benefits received. "Overall Impact of Taxes and Spending on Poverty and Inequality" presents the incidence of taxes and spending as well as the impacts of fiscal policy on poverty and inequality. "Progressivity, Marginal Contributions, and Pro-Poorness of Taxes and Transfers" discusses these measurements of each of the fiscal interventions analyzed. The concluding section summarizes the findings and policy implications of the analysis.

\section{Structure of Taxes and Spending}

\section{Taxes}

On the revenue side, the structure of Ethiopia's tax system shares important features with other CEQ low- and middle-income economies-particularly, their reliance on indirect taxes (figure 1) and international trade (Besley and Persson 2009). Of Ethiopia's total tax revenue in 2011, indirect taxes consistently contributed about 67 percent of the general government's tax 
collection, with the bulk of indirect taxes collected from imports (table 1). In 2011, import taxes contributed 40 percent of the total tax collection.

Our analysis focuses on the major tax items, namely personal income tax (PIT), land use fees, value added tax (VAT), import duties, and specific excise duties on alcohol and tobacco. The analysis of direct taxes focuses on PIT and land use fees. Corporate taxes are not included given the difficulty of attributing the tax burden to specific households. The analysis of indirect taxes focuses on the VAT, import duties, and excise taxes.

Figure 1. Composition of Taxes in Ethiopia and Other Selected CEQ Countries, Ranked by GNI Per Capita

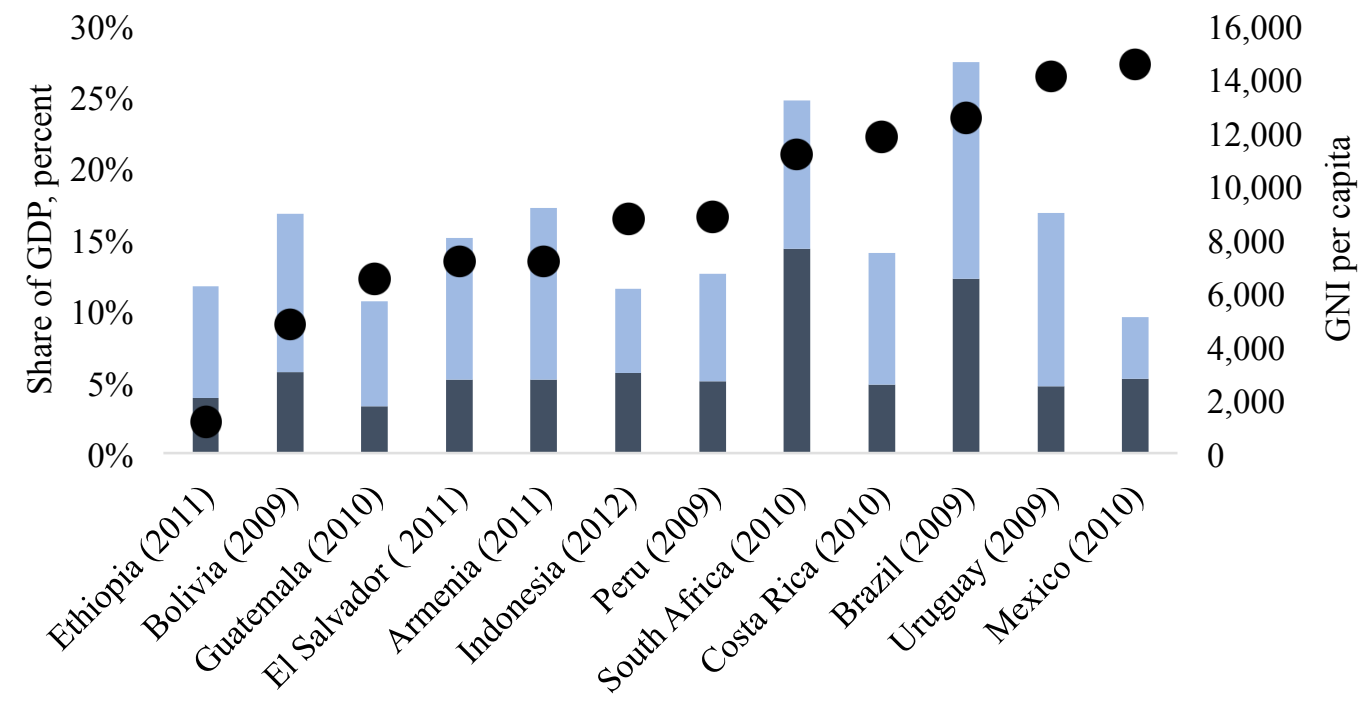

- Direct Tax 1/ Indirect Tax OGNI per capita (2011 PPP, right axis)

Sources: Beneke, Lustig, and Oliva, 2018 (El Salvador); Bucheli et al. 2014 (Uruguay); Cabrera, Lustig, and Morán 2014 (Guatemala); Higgins and Pereira 2014 (Brazil); Jaramillo 2014 (Peru); Paz Arauco et al. 2014 (Bolivia); Sauma and Trejos 2014 (Costa Rica); Scott 2014 (Mexico); World Bank estimates based on 2010/11 Household Consumption Expenditure Survey (HCES) (Ethiopia). Armenia, Indonesia, and South Africa data are from Younger and Khachatryan (2017), Afkar, Jellema and Wai-Poi (2017), and Inchauste, Lustig, Maboshe, Purfield, Woolard and Zikhali (2017), respectively.

Note: $\mathrm{CEQ}=$ Commitment to Equity Project. PPP = purchasing power parity. The year of each country's household survey is shown within parentheses.

a. Direct taxes include both personal and corporate income tax collections.

\section{Direct Taxes}

PIT is levied on individual taxable income, filing is done individually, and the system does not 
provide deductions for married persons or children. All formal sector employees must be registered by their employers for PIT, and the employers are responsible for calculating and withholding the PIT payable.

Table 1. Tax Revenue Structure in Ethiopia, 2011

\begin{tabular}{lccc}
\hline \multicolumn{1}{c}{ Revenue category } & $\begin{array}{c}\text { Br, } \\
\text { millions }\end{array}$ & $\begin{array}{c}\text { Share of tax } \\
\text { revenue (\%) }\end{array}$ & $\begin{array}{c}\text { Share of } \\
\text { GDP (\%) }\end{array}$ \\
& & & \\
\hline Total tax revenue & 58,986 & 100.0 & 11.7 \\
Direct taxes & 19,554 & 33.2 & 3.9 \\
Personal income tax & 5,733 & 9.7 & 1.1 \\
Corporate income tax & 10,055 & 17.0 & 2.0 \\
Agricultural income and rural land use fee & 628 & 1.1 & 0.1 \\
Rental income & 377 & 0.6 & 0.1 \\
Other direct taxes & 2,761 & 4.7 & 0.5 \\
Indirect taxes & 39,432 & 66.8 & 3.8 \\
Domestic indirect taxes & & \\
& 15,706 & 26.6 & 4.7 \\
Import duties, surcharges, and taxes on & & & \\
imports & 23,726 & 40.2 & \\
& & & \\
\hline
\end{tabular}

Source: World Bank estimates based on Ministry of Finance and Economic Development (MoFED) 2011 government finance accounts.

Note: $\mathrm{Br}=$ birr.

a. Domestic indirect taxes include local value added, excise, and other sales taxes on domestic goods and services.

The tax rates were proclaimed in 2002 and have not been adjusted since. As a result, high inflation has caused rises in nominal wages, which have moved income earners upward within the different income brackets.

Beyond the PIT, fees on land use account for about 1 percent of total taxes. These are fees levied for the right to use land in both urban and rural areas. The rates vary by region and depend on the land use type. 


\section{Indirect Taxes}

The VAT rate of 15 percent is the largest component of indirect taxes, when considering collections from domestic production and imports. The VAT exemptions on various goods and services — most of which are aimed at favoring low-income groups-include unprocessed food items, medicine, kerosene, electricity, water, and transport. ${ }^{7}$

Excise taxes are levied on goods that are deemed to be either luxuries or harmful to health, such as alcoholic beverages, tobacco, electronics, textiles, garments, and motor vehicles (whether imported or produced locally). The rates range from 10 percent (on items such as textile products) to 100 percent (on items such as perfumes, alcohol, tobacco, and high-power personal vehicles).

Taxes on imports amount to 40 percent of total tax collection, with import duties accounting for 13 percent of tax revenue. The simple average tariff rate is 16.7 percent, and rates reach a maximum of 35 percent depending on the type of commodity. Exemptions from import duties or other taxes are granted for raw materials that are necessary for the production of export goods and selected investment items. In addition to import duty, a 10 percent surcharge on imported consumer imports was introduced in 2007 and has been implemented to date. Together, import duties and surcharges contribute to over 20 percent of total tax revenue. The remaining 20 percent comes from VAT and excise taxes on imports.

\section{Spending}

Public spending is guided by Ethiopia's Growth and Transformation Plan (GTP) and is particularly targeted to the pro-poor sectors identified in this plan (MoFED 2010; NPC 2016). The combination of social spending and subsidies in Ethiopia (7.8 percent of GDP) are about as high as in Armenia (7.7 percent) and higher than in Guatemala or Peru (5.8 percent and 6.3 percent, respectively), all of which have considerably higher incomes per capita and higher tax revenues than Ethiopia (figure 2).

\footnotetext{
${ }^{7}$ VAT-exempted goods and services are the following: sale or transfer of a used dwelling or the lease of a dwelling; financial services; the supply or import of national or foreign currency and of securities; import of gold to be transferred to the National Bank of Ethiopia; services of religious organizations; medicines and medical services; educational services and childcare services for children at preschool institutions; goods and services for humanitarian aid and rehabilitation after natural disasters, industrial accidents, and catastrophes; electricity, kerosene, and water; goods imported by the government, organizations, or institutions or projects exempted from duties and other import taxes to the extent provided by law or by agreement; postal service; transport; permits and license fees; goods or services by a workshop employing disabled individuals if more than 60 percent of the employees are disabled; books and other printed materials; unprocessed food items; palm oils used for food; bread; and "injera," or milk.
} 
Figure 2. Composition of Spending and Subsidies in Ethiopia and Other Selected CEQ Countries, Ranked by GNI Per Capita

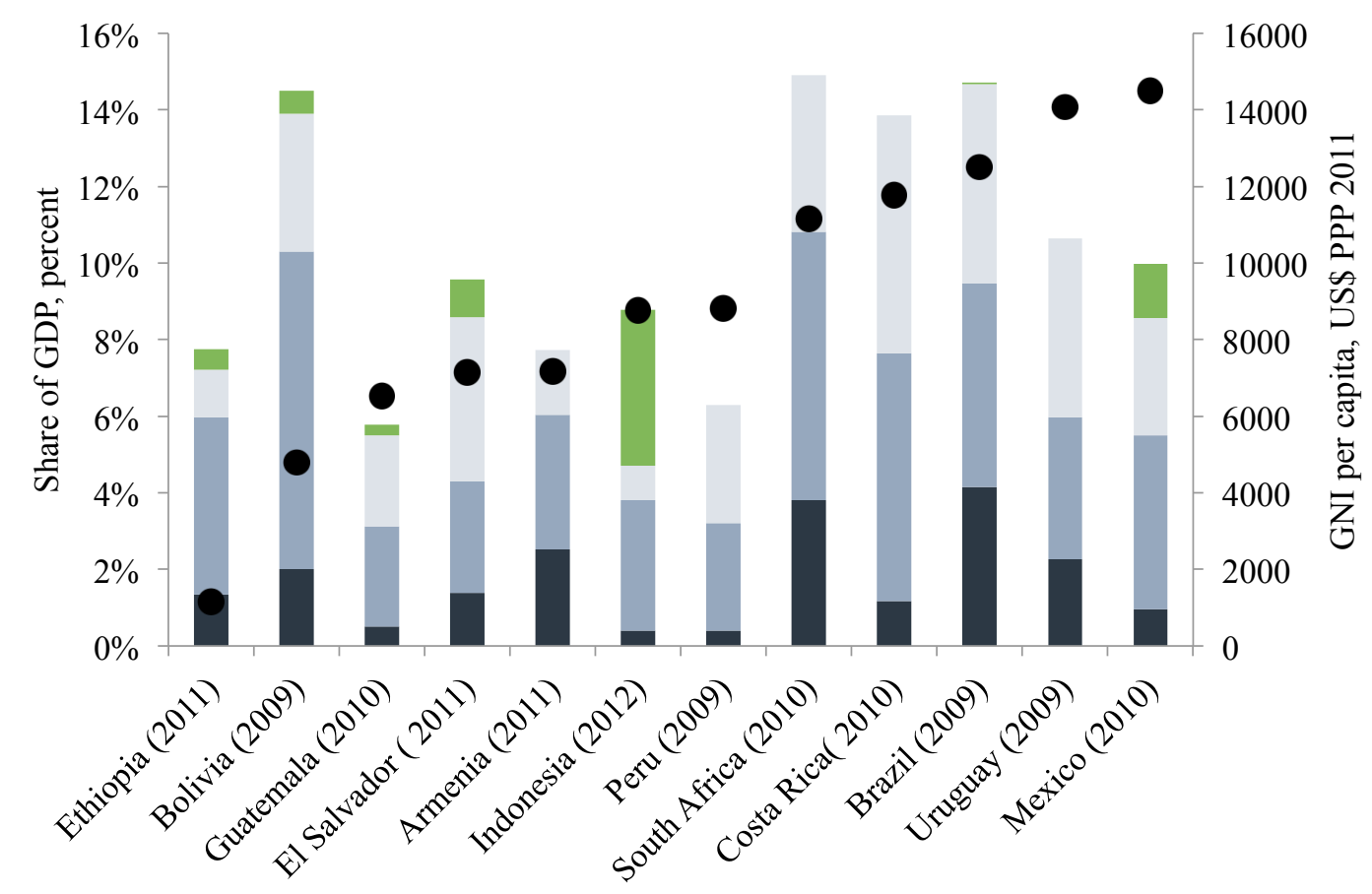

-Direct Transfer $\square$ Education $\square$ Health $\square$ Subsidies $\bullet$ GNI per capita (2011 PPP, right axis)

Sources: Beneke, Lustig, and Oliva, 2018 (El Salvador); Bucheli et al. 2014 (Uruguay); Cabrera, Lustig, and Morán 2014 (Guatemala); Higgins and Pereira 2014 (Brazil); Jaramillo 2014 (Peru); Paz Arauco et al. 2014 (Bolivia); Sauma and Trejos 2014 (Costa Rica); Scott 2014 (Mexico); World Bank estimates based on 2010/11 Household Consumption Expenditure Survey (HCES) (Ethiopia). Armenia, Indonesia, and South Africa data are from Younger and Khachatryan (2017), Afkar, Jellema and Wai-Poi (2017), and Inchauste, Lustig, Maboshe, Purfield, Woolard and Zikhali (2017), respectively.

Note: $\mathrm{CEQ}=$ Commitment to Equity Project. $\mathrm{PPP}=$ purchasing power parity. The year of each country's household survey is shown within parentheses.

The pro-poor sectors identified in the GTP are agriculture and food security, education, health, roads, and water; accordingly, nearly 70 percent of total general government expenditure is allocated to these sectors (table 2). Education spending makes up the highest share of total spending ( 25 percent), followed by roads and agriculture at 20 percent and 15 percent, respectively. About half of the agricultural budget is allocated to ongoing food security and to a large rural safety net program, the Productive Safety Net Program (PSNP). Finally, health spending accounts for about 7 percent of the general government budget. 


\begin{tabular}{|c|c|c|c|}
\hline Expenditure category & Br, millions & $\begin{array}{l}\text { Share of general } \\
\text { government } \\
\text { expenditure }(\%)\end{array}$ & $\begin{array}{c}\text { Share of } \\
\text { GDP } \\
(\%)\end{array}$ \\
\hline Total general government expenditure & 93,831 & 100.0 & 18.6 \\
\hline General services & 15,655 & 16.7 & 3.1 \\
\hline Economic development & 38,422 & 40.9 & 7.6 \\
\hline Agriculture & 14,183 & 15.1 & 2.8 \\
\hline Productive Safety Net Program & 5,293 & 5.6 & 1.0 \\
\hline Food security & 1,510 & 1.6 & 0.3 \\
\hline Roads & 18,318 & 19.5 & 3.6 \\
\hline Other & 5,921 & 6.3 & 1.2 \\
\hline Social development & 32,936 & 35.1 & 6.5 \\
\hline Education & 23,345 & 24.9 & 4.6 \\
\hline Health & 6,307 & 6.7 & 1.2 \\
\hline Urban development and housing & 2,762 & 2.9 & 0.5 \\
\hline Labor and social welfare & 179 & 0.2 & 0.0 \\
\hline Other & 343 & 0.4 & 0.1 \\
\hline Other & 6,818 & 7.3 & 1.3 \\
\hline $\begin{array}{l}\text { Off-budget indirect subsidies (kerosene, } \\
\text { electricity, and wheat) }\end{array}$ & 2,743 & n.a. & 0.5 \\
\hline
\end{tabular}

Source: World Bank estimates based on Ministry of Finance and Economic Development, 2011 government finance accounts.

Note: $\mathrm{Br}=$ birr. n.a. $=$ not applicable.

In addition, the government subsidized electricity, kerosene, and wheat in 2011 through the operations of Ethiopian Electric Power Corporation (EEPCo), the Oil Stabilization Fund, and Ethiopian Grain Trade Enterprise (EGTE). These expenditures (off-budget operations not included in general government finance) were as follows:

- Electricity subsidies to households, the primary indirect subsidy, totaled an estimated $\mathrm{Br} 1.5$ billion (equivalent to 0.3 percent of GDP).

- Kerosene, subsidized through the Oil Stabilization Fund, amounted to Br 0.7 billion (0.14 percent of GDP). 
- Wheat was subsidized by government to reduce the effect of food inflation on the urban poor through a program of import and distribution of wheat in Addis Ababa at a subsidized price. The transfer was not targeted, and the sales were rationed to all households of the city through local administrative units (kebeles). The estimated subsidy was $\mathrm{Br} 150$ per quintal of wheat, amounting to total spending of $\mathrm{Br} 0.5$ billion (0.1 percent of GDP).

The incidence analysis covers 33 percent of all government spending (mostly social spending), but it excludes infrastructure spending on education (see appendix). It assesses the incidence of spending on education, health, and the PSNP. Spending on general services and roads was not included, given the difficulty of attributing benefits to specific households. Non-PSNP agricultural spending and spending on urban development and housing were not included in the analysis at this stage, given data challenges, but can be considered in future work. However, the fiscal analysis does include the off-budget electricity, kerosene, and wheat subsidies.

\section{Data Sources and Assumptions}

\section{Data Sources}

Data for fiscal year 2010/11 were used to conduct this incidence analysis study, in line with the availability of survey data. Specifically, we used the 2010/11 Household Consumption Expenditure Survey (HCES) ${ }^{8}$ and Welfare Monitoring Survey (WMS) collected by the Central Statistical Agency (CSA) of Ethiopia. Those surveys are the main data sources used by the Ethiopian government to monitor its poverty reduction strategies. The WMS has detailed information on individual occupations, age, and access to various services including education, health, and agricultural extension. The HCES and WMS data are complemented by the Ethiopian Rural Socio-Economic Survey (ERSS), which is collected by the World Bank in collaboration with the CSA.

Household survey data are combined with data from national income and public finance accounts from the Ministry of Finance and Economic Development (now known as the Ministry of Finance and Economic Cooperation). These accounts provide the public revenue and expenditures corresponding to the 2010/11 Ethiopian fiscal year. Complementing this information are data from the 2010/11 Annual Work Plan for the PSNP and Household Asset Building Program (HABP); the Ministry of Trade; the World Bank's 2013 "Report on Accountability Issues" to EEPCo; and the Ministry of Health. Finally, we use the 2005 social accounting matrix (SAM) produced by the Ethiopian Development Research Institute (EDRI) to estimate the effect of indirect taxes as described below.

\footnotetext{
88 Although the survey was conducted in 2010/11, all expenditure data were deflated to December 2010. The PPP conversion is made after adjusting the relative difference between the consumer price index in 2005 and December 2010.
} 


\section{Assumptions}

Because the HCES does not report income data, the analysis assumes that consumption is equal to "disposable income" and works backward and forward to construct the other CEQ income concepts. The income concept for Ethiopia is based on consumption value from the HCES. Consumption expenditures from all sources are included in the consumption aggregate, including autoconsumption, gifts and proceeds from the sale of durables, and imputed rent for owner-occupied housing. Total household consumption is set to equal disposable income, to which taxes and transfers are subtracted or added to obtain the CEQ income concepts described in Inchauste and Lustig (2017).

\section{Taxes}

We make a simple assumption on the economic incidence of taxes: direct taxes are borne entirely by the income earner and indirect taxes entirely by the consumer. This latter part of this assumption is not entirely appropriate if markets are not competitive-and, in Ethiopia, many are not. However, the extent to which monopolies or oligopolies shift indirect taxes to consumers is not clear; it could be either greater or less than 100 percent depending on the functional form of the demand function (Fullerton and Metcalf 2002). Since we have no information on those functional forms, we assume that 100 percent of taxes are shifted to consumers regardless of market structure.

\section{Direct Taxes}

To allocate taxes across households, note that the HCES does not provide information on PIT. Thus, the burden of these taxes had to be simulated. Consistent with other conventional tax incidence analyses, we assume that the economic burden of PIT is borne by the income earner. Tax evasion (the difference between actual PIT collected and estimated tax based on income) is assumed to be borne by all self-employed and employees of the informal sector in proportion to income.

Agricultural income taxes and rural land use fees are calculated on the basis of landholding size reported in the ERSS because the landholding size collected in the 2010/11 HCES often did not record standardized units. The tax schedule for this tax and fee is set by regional and local governments and, as such, varies from locale to locale. However, many of the main tax schedules were examined and found to levy similar per hectare tax rates regardless of land size. A region's total tax revenue was divided by its total agricultural land holdings to generate an average tax rate per hectare. This rate was used with the imputed land size in each region to estimate the amount of agricultural tax paid by each household. This method assumes a constant rate per region, but it takes into account potential evasion as it is based on actual collections. 


\section{Indirect Taxes}

The burden of indirect taxes is estimated using detailed consumption data in the HCES and the SAM developed in 2006 by EDRI. The SAM's input-output table provides information on indirect taxes collected and the total supply value of each of the 93 commodity accounts. This information is used to calculate an effective tax rate for each of those commodities and to draw a correspondence between the SAM accounts and the item-level consumption in the HCES data. With this, we estimated the price burden on each household based on the proportional increase in the price of each good and services and the household's expenditure on corresponding goods and services, which is assumed to be borne entirely by the consumers. We also estimated the second-round effects of indirect taxes, defined as the price burden on consumers resulting from indirect taxes paid for inputs used in the production process. The input-output table is used to calculate the effect of taxes on intermediate inputs on prices of final goods and services.

For VAT, we consider two scenarios: (a) one in which VAT refunds do not properly work so that VAT works as a sales tax; and (b) one in which the indirect effects are only considered in the case of exempt items, since VAT refunds ensure that there is no cascading of nonexempt items. (See appendix for more details.)

\section{Transfers}

On the spending side, the 2010/11 HCES provides detailed information on which households received PSNP payments and food aid. The beneficiary status of the household and household size were used in conjunction with government expenditure data to impute the value of transfers received by each household, assuming that all food aid and PSNP transfers were distributed equally across beneficiaries.?

Indirect subsidies are estimated using item-level HCES data, which provide households' consumption of wheat, kerosene, and electricity. The subsidy per kilogram, liter, and kilowatthour for each good, respectively, was then applied to estimate the total value of the subsidy received by the household.

To estimate the incidence of public spending (in-kind transfers) on education and health, we use the "government cost" approach. In essence, we use per beneficiary input costs obtained from administrative fiscal data as the measure of average benefits. This approach is also known as the "classic" or "nonbehavioral approach," and it amounts to asking the following question: how much would the income of a household have to be increased if it had to pay for the free or subsidized public service at the full cost to the government? The WMS provides information on educational enrollment by level and type (public versus private institutions), which is combined with regional expenditures on education by level. For health spending,

\footnotetext{
${ }^{9}$ It may be that better-off households do not work the same number of days as less-well-off households. If so, the assumption of equal distribution of benefits would make the PSNP appear less progressive than it actually is.
} 
curative services are estimated in proportion to households' expenditure on public health fees, while preventive service benefits are distributed to all households equally. ${ }^{10}$

\section{General Caveats}

To these assumptions, we must add several important caveats about what this fiscal incidence analysis does not address:

- It does not take into account behavioral, life-cycle, or general equilibrium effects and focuses on average incidence rather than incidence at the margin. Our tax-shifting and labor-supply response assumptions are strong because they imply that consumers have perfectly inelastic demand and that labor supply is perfectly inelastic, too. In practice, they provide a reasonable approximation, and they are commonly used.

- It does not take into account intrahousehold distribution of consumption.

- It cannot take into account the quality of services delivered by the government.

- It cannot include some important taxes and spending. Corporate income taxes and spending on infrastructure investments, including urban services and rural roads, are excluded even though such taxes and investments affect income distribution and poverty.

- It does not capture the growing debate on how asset accumulation and returns to capital affect income inequality.

The Ethiopian social security system provides income security in old age, disability, or death only to public servants. As such, contributions are treated as savings and are considered part of market income for public sector workers.

\section{Overall Impact of Taxes and Spending on Poverty and Inequality}

\section{Impact on Inequality}

Table 3 reports Ethiopia's Gini coefficients and the poverty headcount ratios by CEQ income concept. It shows that fiscal policy contributes to reducing Ethiopia's "market income" inequality (market income being income received before any taxes are paid or transfers received).

At 0.322 , the market-income Gini coefficient is low relative to other countries. The simple worldwide unweighted average was 0.371 in 2013 and 0.438 in Sub-Saharan Africa (World Bank 2016). Using expenditure per capita (instead of income) as the starting welfare indicator, fiscal policy reduces the market-income Gini coefficient from 0.322 to 0.302 - a decline of 2

\footnotetext{
${ }^{10}$ Details on the assumptions used for education and health incidence are included in the appendix.
} 
percentage points - when taxes (PIT, land taxes, VAT, import duties, and excise taxes) and transfers (cash transfers, subsidies, and the monetized value of education and health) are taken into account.

Once in-kind transfers are included (as part of "final income"), the net impact of all fiscal policy is progressive, with all but the top 20 percent receiving more benefits relative to their market incomes than the taxes they pay (figure 3). As a result, fiscal policy reduces inequality in Ethiopia.

Table 3. Poverty and Inequality Indicators in Ethiopia, by CEQ Income Concept, 2011

\begin{tabular}{|c|c|c|c|c|}
\hline Indicator & $\begin{array}{l}\text { Market } \\
\text { income }^{a}\end{array}$ & $\begin{array}{c}\text { Disposable } \\
\text { income }^{b}\end{array}$ & $\begin{array}{c}\text { Consumable } \\
\text { income }^{c}\end{array}$ & $\begin{array}{c}\text { Final } \\
\text { income }^{d}\end{array}$ \\
\hline \multicolumn{5}{|l|}{ National poverty line } \\
\hline Poverty incidence $(\%)$ & 31.2 & 30.2 & 32.4 & n.a. \\
\hline Poverty gap ${ }^{\mathrm{f}}(\%)$ & 9.0 & 7.9 & 8.7 & n.a. \\
\hline Poverty severity ${ }^{\mathrm{f}}(\%)$ & 4.3 & 3.1 & 3.4 & n.a. \\
\hline \multicolumn{5}{|l|}{ US\$1.25 a day 2005 PPP } \\
\hline Poverty incidence ${ }^{\mathrm{f}}(\%)$ & 31.9 & 30.9 & 33.2 & n.a. \\
\hline Poverty gap ${ }^{f}(\%)$ & 9.2 & 8.2 & 8.9 & n.a. \\
\hline Poverty severity ${ }^{\mathrm{f}}(\%)$ & 3.9 & 3.2 & 3.5 & n.a. \\
\hline Gini coefficients (\%) & 0.322 & 0.305 & 0.302 & 0.302 \\
\hline
\end{tabular}

Source: Based on 2011 Household Consumption Expenditure Survey (HCES) and 2011 Welfare Monitoring Survey (WMS) data.

Note: n.a. = not applicable (not included in the analysis; see note “d.”). PPP = purchasing power parity.

a. "Market income" comprises pretax wages, salaries, income earned from capital assets (rent, interest, or dividends), and private transfers.

b. "Disposable income" = market income - personal income taxes and social security contributions + direct cash transfers.

c. "Consumable income" $=$ disposable income - indirect (sales and excise) taxes + indirect subsidies.

d. "Final income" = consumable income + in-kind transfers for education and health care. Poverty rates are not calculated by final income because households may not be aware of the amounts spent on their behalf and may not value this spending as much as a direct cash transfer. Hence, the analysis does not assume that this spending improves their welfare by a corresponding amount.

e. The national poverty line is defined by the value that affords consumption of 2,200 kilocalories per day per adult plus essential nonfood expenditure. 
f. "Poverty incidence" is the percentage of the population that is poor. The "poverty gap" (or depth) is the average percentage by which individuals fall below the poverty line. "Poverty severity" (or intensity) is calculated as the poverty gap index squared; it implicitly gives greater weight to the poorest individuals, making it a combined measure of poverty and income inequality. These three poverty metrics are known as the FosterGreer-Thorbecke (FGT) indexes (Foster, Greer, and Thorbecke 1984).

g. The Gini index measures the equality of income distribution, ranging from zero (perfect equality) to one (maximal inequality).

Figure 3. Incidence of Taxes and Transfers and Net Fiscal Benefit, by Market Income Decile, in Ethiopia, 2011

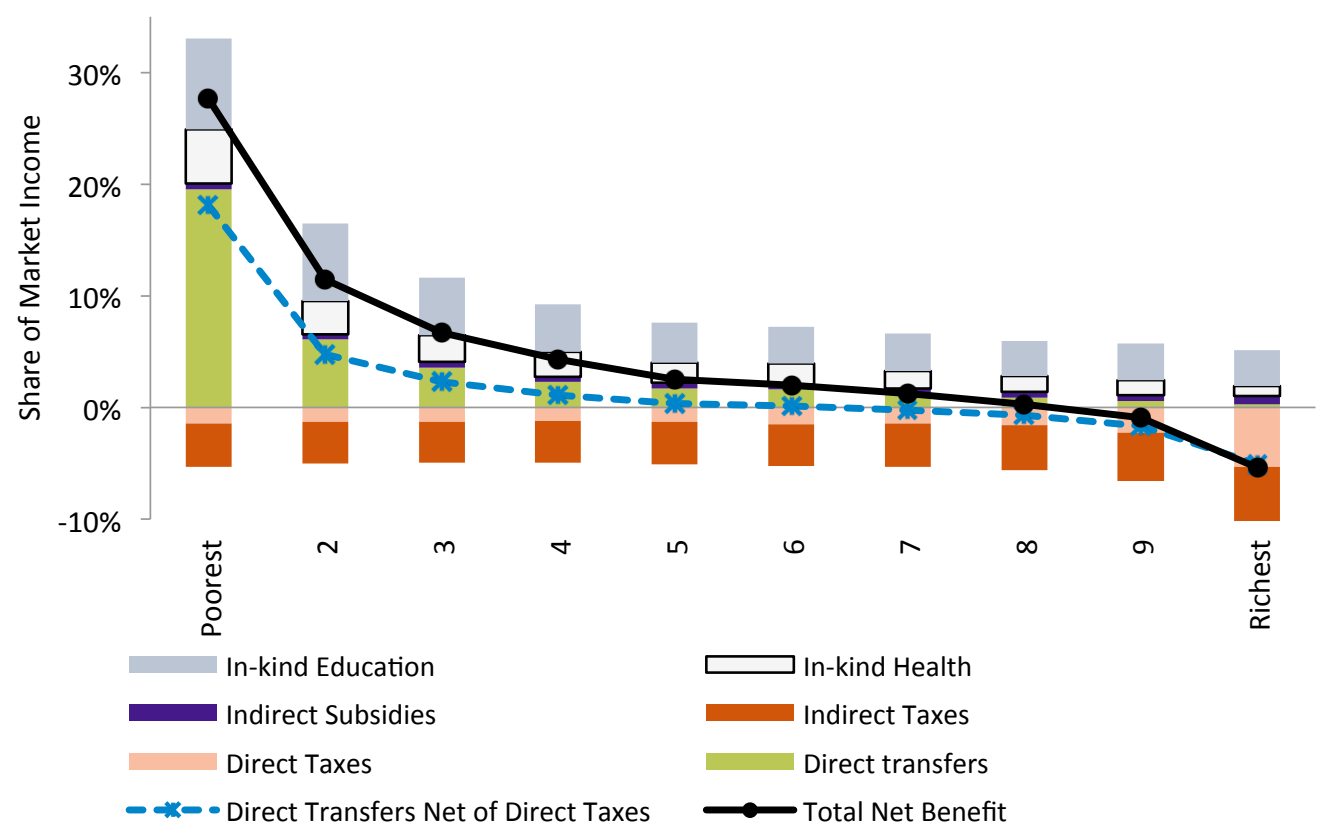

Source: Based on 2011 Household Consumption Expenditure Survey (HCES) and 2011 Welfare Monitoring Survey (WMS) data.

Note: Market income comprises pretax wages, salaries, income earned from capital assets (rent, interest, or dividends), and private transfers. Income deciles range from 1 (poorest) to 10 (richest).

\section{Impact on Poverty}

Despite the decline in inequality, the results also show an increase in poverty as a result of taxes and transfers. The combined effect of taxes, cash transfers, and subsidies is to increase the incidence of extreme poverty (at the international per capita poverty line of US $\$ 1.25$ per day in 2005 PPP) from 31.9 percent (at market income) to 33.2 percent (at consumable income) (table 3). The same is true if using the national poverty line: the poverty headcount rate increases from 31.2 percent (at market income) to 32.4 percent (at consumable 
income $)^{11}$ — a signal that total government transfers and subsidies do not make up for the impact of indirect taxes around the poverty line.

Following standard conventions, this analysis refrains from calculating poverty rates after inkind health and education transfers because households may not be aware of the actual amount spent on their behalf and may not value this spending as much as they would a direct cash transfer. Hence, the analysis does not assume that the monetized value of in-kind transfers improves their monetary welfare by a corresponding amount, nor can it describe the long-run welfare of health and education spending. However, figure 3 indicates that spending on education and health does offset the impact of indirect taxes around the poverty line, a point discussed further below.

Table 4. Extent of Impoverishment by Fiscal Policy in Ethiopia, 2011

Percentage of population, by type

\begin{tabular}{|c|c|c|}
\hline Impoverishment headcount index comparison & $\begin{array}{c}\text { National } \\
\text { poverty line }\end{array}$ & $\begin{array}{c}\text { US } \$ 1.25 \\
\text { per day, } \\
\text { PPP } 2005\end{array}$ \\
\hline \multicolumn{3}{|l|}{ Poor population that became poorer } \\
\hline $\begin{array}{l}\text { Market income } \rightarrow(- \text { direct taxes }+ \text { direct transfers }) \rightarrow \text { disposable } \\
\text { income }\end{array}$ & 25.0 & 25.6 \\
\hline $\begin{array}{l}\text { Market income } \rightarrow \text { ( }- \text { all taxes }+ \text { direct and in-kind transfers }) \rightarrow \\
\text { final income }\end{array}$ & 9.1 & 9.3 \\
\hline \multicolumn{3}{|l|}{ Nonpoor population that became poor } \\
\hline $\begin{array}{l}\text { Market income } \rightarrow(- \text { direct taxes }+ \text { direct transfers }) \rightarrow \text { disposable } \\
\text { income }\end{array}$ & 0.9 & 0.9 \\
\hline $\begin{array}{l}\text { Market income } \rightarrow \text { (- all taxes }+ \text { direct and in-kind transfers }) \rightarrow \\
\text { final income }\end{array}$ & 1.1 & 0.9 \\
\hline
\end{tabular}

Source: Based on 2011 Household Consumption Expenditure Survey (HCES) and 2011 Welfare Monitoring Survey (WMS) data.

Note: PPP = purchasing power parity. The "impoverishment headcount index," developed by Higgins and Lustig (2015), measures the percentage of the population impoverished by the tax and transfer system as a proportion of the post-fisc poor. "Market income" comprises pretax wages, salaries, income earned from capital assets (rent, interest, or dividends), and private transfers. "Disposable income" = market income - direct taxes + direct transfers. "Final income" = disposable income - indirect taxes + indirect subsidies + in-kind transfers.

a. The national poverty line is defined by the value that affords consumption of 2,200 kilocalories per day per adult plus essential nonfood expenditure.

\footnotetext{
11 Typically, Ethiopia measures welfare using a household consumption aggregate, which we set as equal to disposable income. Using the national moderate poverty line (2,200 kilocalories per day per adult plus essential nonfood expenditure), the poverty headcount is 30 percent, coinciding with the official headcount rate for $2010 / 11$
} 
Note that although the headcount ratio goes up, the poverty gap and poverty severity (the poverty gap squared) are lower for consumable income than for market income. Although this finding is reassuring - indicating that fiscal policy reduces the depth and severity of povertyit can also be misleading. Standard poverty measures can fail to capture the extent to which the poor are further impoverished by tax and benefit systems (Higgins and Lustig 2016). To assess the latter, we use Higgins and Lustig's "fiscal impoverishment headcount index," which measures the percentage of the population impoverished by the tax and transfer system as a proportion of the post-fisc poor. "Impoverished" households are those that were either (a) nonpoor before taxes and transfers and made poor by the fiscal system, or (b) poor before taxes and transfers and made even poorer by the fiscal system.

Table 4 summarizes the impoverishment indexes, at both the national and US\$1.25-a-day poverty lines, using two income-concept comparisons: from market to disposable income and from market to final income. This analysis finds that direct taxes made a quarter of the poor population poorer, even when taking direct transfers into account. When all of the measured taxes paid and benefits received are considered (that is, by moving from market income to final income), fiscal policy still further impoverishes 9 percent of the poor. In both income-concept comparisons, about 1 percent of the nonpoor population became poor.

\section{Progressivity, Marginal Contributions, and Pro-Poorness of Taxes and Transfers}

To measure the progressivity of particular fiscal interventions, the analysis uses both a standard progressivity measure (the Kakwani coefficient) and a calculation of each intervention's "marginal contribution" to inequality and poverty reduction. The former is calculated by subtracting an intervention's concentration coefficient from the market-income Gini; progressive interventions have positive Kakwani coefficients, and regressive ones have negative coefficients (Kakwani 1977). On the other hand, the "marginal contribution" is the difference in the Gini or poverty headcount for an income concept with and without a given intervention.

\section{General Results}

Beginning with the Kakwani progressivity index for taxes and transfers and their respective marginal contributions (discussed in further detail below), the results show that both direct taxes and indirect taxes are progressive, with the Kakwani index being positive in both cases (table 5). ${ }^{12}$ However, among direct taxes, the agricultural income land use fee and the chat tax (a tax on any person transporting or handling chat-the leaves or buds of the plant more commonly spelled "khat," which is chewed or used in tea for its stimulant properties-for commercial purposes) are regressive as well as both inequality- and poverty-increasing. Interestingly, indirect taxes are redistributive, reducing inequality by 0.339 Gini points. This is

\footnotetext{
${ }^{12}$ We assume that effective tax rates are equal across households, which may underestimate the progressivity of indirect taxes (if richer urban households are more likely to purchase in formal markets).
} 
Table 5. Marginal Contribution of Taxes and Transfers to Inequality and Poverty Reduction in Ethiopia, 2011

\begin{tabular}{|c|c|c|c|c|}
\hline \multirow[b]{2}{*}{ Type of fiscal intervention } & \multirow[b]{2}{*}{$\begin{array}{l}\text { Size }^{a} \\
(\%)\end{array}$} & \multirow[b]{2}{*}{$\begin{array}{c}\text { Kakwani } \\
\text { coefficient }^{b}\end{array}$} & \multicolumn{2}{|c|}{ Marginal contribution ${ }^{c}$} \\
\hline & & & $\begin{array}{c}\text { Redistributive } \\
\text { effect }^{\text {d }} \\
\text { (change, Gini } \\
\text { points) }\end{array}$ & $\begin{array}{c}\text { Poverty } \\
\text { reduction } \\
\text { effect }^{\mathrm{e}}\end{array}$ \\
\hline \multicolumn{3}{|c|}{ Total from market to consumable income } & 1.9284 & -1.9550 \\
\hline Direct taxes & 2.58 & 0.28 & 0.7162 & -1.1723 \\
\hline Personal income tax & 2.39 & 0.30 & 0.7216 & -1.0127 \\
\hline Agricultural income land use fee & 0.08 & -0.20 & -0.0132 & -0.0938 \\
\hline Rental tax & 0.07 & 0.13 & 0.0030 & -0.0545 \\
\hline Chat $\operatorname{tax}^{\mathrm{f}}$ & 0.03 & -0.05 & -0.0005 & -0.0318 \\
\hline Direct transfers & 1.93 & 0.69 & 1.1812 & 2.0676 \\
\hline Productive Safety Net Program & 1.55 & 0.72 & 0.9925 & 1.6274 \\
\hline Food aid & 0.38 & 0.55 & 0.1616 & 0.5634 \\
\hline Indirect subsidies & 0.56 & -0.07 & -0.0330 & 0.3564 \\
\hline Electricity subsidy & 0.38 & -0.14 & -0.0455 & 0.2257 \\
\hline Kerosene subsidy & 0.16 & 0.07 & 0.0098 & 0.1196 \\
\hline Wheat subsidy & 0.01 & 0.04 & 0.0022 & 0.0097 \\
\hline Indirect taxes & 5.60 & 0.05 & 0.3391 & -3.6542 \\
\hline \multicolumn{3}{|l|}{ Total from market to final income } & 2.2072 & 2.3172 \\
\hline Direct taxes & 2.58 & 0.28 & 0.7157 & -0.9589 \\
\hline Direct transfers & 1.93 & 0.69 & 1.1032 & 2.2000 \\
\hline Indirect subsidies & 0.56 & -0.07 & -0.0437 & 0.3910 \\
\hline Indirect taxes & 5.60 & 0.05 & 0.3364 & -3.6349 \\
\hline In-kind transfers & 5.46 & 0.17 & - & n.a. \\
\hline
\end{tabular}




\begin{tabular}{|l|l|l|l|l|}
\hline Education & 3.80 & 0.14 & -0.0392 & n.a. \\
\hline Primary school & 1.67 & 0.35 & 0.5242 & n.a. \\
\hline Secondary school & 0.98 & 0.05 & -0.0353 & n.a. \\
\hline Tertiary & 1.15 & -0.09 & -0.5312 & n.a. \\
\hline Health & 1.66 & 0.25 & 0.3063 & n.a. \\
\hline
\end{tabular}

Source: Based on 2011 Household Consumption Expenditure Survey (HCES) and 2011 Welfare Monitoring Survey (WMS) data.

Note: n.a. = not applicable (not included in analysis; see note “e.”). - = not available (not calculated). pp = percentage points. "Market income" comprises pretax wages, salaries, income earned from capital assets (rent, interest, or dividends), and private transfers. "Consumable income" = market income - direct and indirect taxes + direct cash transfers + indirect subsidies. "Final income" $=$ consumable income + in-kind transfers for education and health care. The Gini index measures the equality of income distribution, ranging from zero (perfect equality) to 100 points (maximal inequality).

a. "Size" equals the ratio of the amount collected or spent divided by total market income.

b. The Kakwani coefficient is calculated by subtracting the concentration coefficient from the market-income Gini; progressive interventions have positive Kakwani coefficients, and regressive ones have negative coefficients (Kakwani 1977).

c. The "marginal contribution" equals the difference between the Gini coefficient or headcount poverty rate of the relevant ending income concept with and without the intervention in question. By definition, the sum of the marginal contributions does not fulfill the adding-up principle, so it will not be equal to the redistributive effect unless by coincidence.

d. The "redistributive effect" equals the difference between market-income Gini coefficient and the relevant ending income concept Gini.

e. The "poverty reduction effect" is based on poverty headcount index using the poverty line of US\$1.25 per day in 2005 PPP. A negative poverty reduction value indicates an increase in poverty. Poverty rates are not calculated by final income because households may not be aware of the amounts spent on their behalf and may not value this spending as much as a direct cash transfer. Hence, the analysis does not assume that this spending improves their welfare by a corresponding amount

f. The "chat tax" is an excise tax on any person transporting or handling chat for commercial purposes. Chat is a major psychoactive component of the plant Catha edulis (khat). The young leaves of khat are chewed for a stimulant effect.

not surprising: given that they account for two-thirds of tax revenue collection (as shown earlier in table 2), they end up financing a large part of social spending. However, as discussed below, they are also poverty-increasing.

Direct cash transfers are progressive in absolute terms. Based on their marginal contribution, they are also strongly redistributive, with the PSNP reducing inequality by 0.993 Gini points. In contrast, the electricity subsidy is regressive and increases inequality by 0.046 Gini points. Kerosene and wheat subsidies are progressive, redistributive, and poverty-reducing. 
In-kind health and primary education are equalizing and poverty-reducing. However, there is heterogeneity across levels of education, with primary education being strongly progressive and redistributive. In contrast, tertiary education is regressive and unequalizing.

\section{Taxes}

\section{Direct Taxes}

Typically the collection of direct taxes is low for lower-income countries (Besley and Persson 2009); however, for Ethiopia's level of GNI per capita, direct tax collection is remarkably high (as shown earlier in figure 1). For example, direct taxes are a higher share of GDP in Ethiopia (3.9 percent) than in Guatemala (3.3 percent) even though Guatemala's GNI per capita is more than five times higher than Ethiopia's.

Moreover, the share of the tax bill paid by Ethiopian households living on less than US $\$ 1.25$ per person per day PPP is extremely high (11 percent) relative to other CEQ countries with substantially higher per capita GNI (Armenia, Bolivia, Brazil, El Salvador, Guatemala, and South Africa), as shown in figure 4. Thus, even though direct taxes are redistributive and could be used for long-term investments in human and physical capital, they are also povertyincreasing in the short term when looking at households' cash position (table 4)-highlighting the fundamental challenge of pro-poor revenue generation in a low-income country.

Figure 4. Concentration of Total Taxes, by Household Income Group, in Ethiopia and Other Selected CEQ Countries

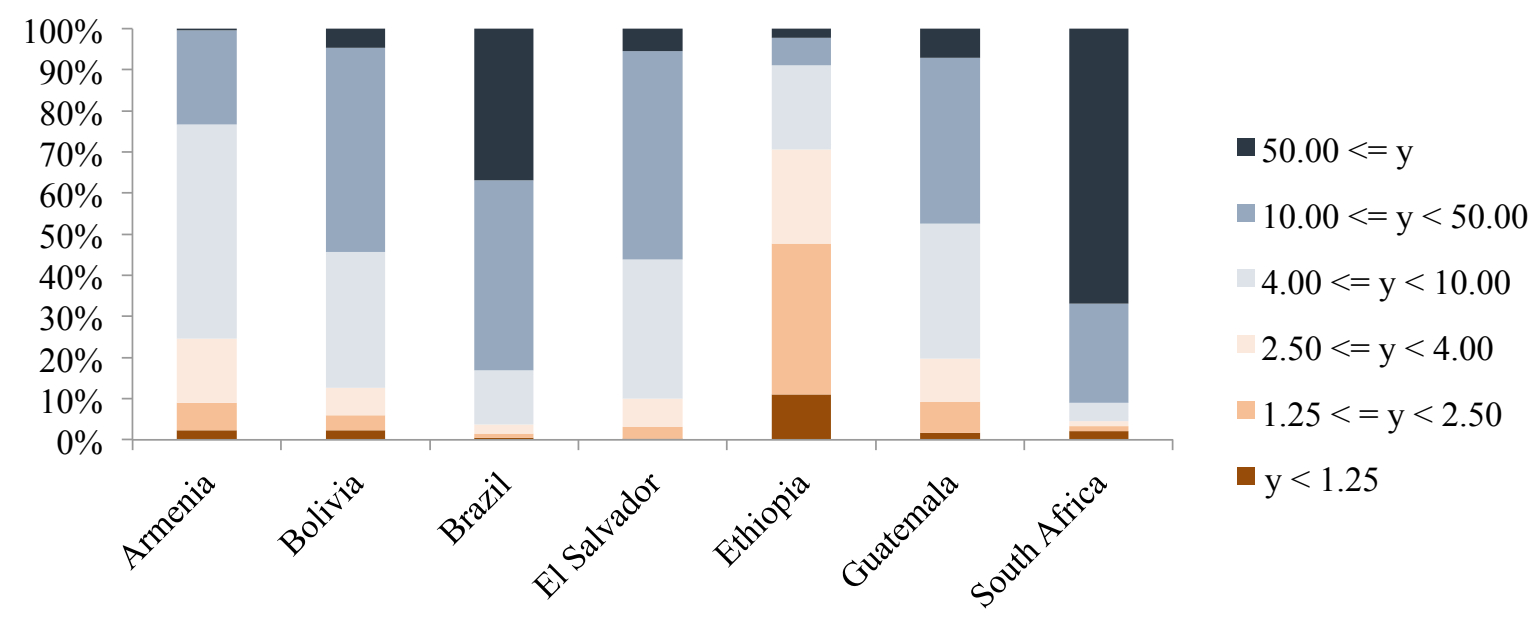

Sources: Beneke, Lustig, and Oliva, 2018 (El Salvador); Cabrera, Lustig, and Morán 2014 (Guatemala); Higgins and Pereira 2014 (Brazil); World Bank estimates based on 2010/11 Household Consumption Expenditure Survey (HCES) (Ethiopia). Armenia and South Africa data are from Younger and Khachatryan (2017) and Inchauste, Lustig, Maboshe, Purfield, Woolard and Zikhali (2017), respectively.

Note: $\mathrm{y}=$ income group. Figure shows the share of taxes paid by households in the per capita income groups shown (using internationally comparable per capita income levels at 2005 purchasing power parity, or PPP). 
PIT generates most of Ethiopia's direct tax revenue, and although it is progressive and equalizing, it is also poverty-increasing (table 5), because any personal income above $\mathrm{Br} 150$ per month (or Br 1,800 per year, equivalent to about US $\$ 112$ in 2011) is taxed. ${ }^{13}$ This threshold is much lower than the poverty line of $\mathrm{Br} 3,781$ per adult equivalent, implying that the poor are effectively paying income taxes. Increasing this minimum cutoff would reduce the direct tax burden on the bottom deciles. The consequent loss in tax revenue could be offset by higher PIT rates on higher deciles.

In contrast, the agricultural income land use fee is regressive, unequalizing, and povertyincreasing (table 5), partly because agricultural households are likely to be poorer than nonagricultural households. In addition, agricultural income tax rules are set by regional and local governments and are mainly levied according to landholding size, which does not necessarily determine income earned. In only a few places are assets such as cattle size also considered. For the most part, per hectare tax rates do not increase with landholding size, and the estimates here assume that this is the case across the country. (In the Oromia region, they tend to slightly fall with landholding size, as detailed in the appendix, table A.2, so this assumption may underestimate the regressivity of these taxes in Oromia.)

\section{Indirect Taxes}

Indirect taxes are progressive and equalizing in Ethiopia as a result of higher tax rates being applied to those goods that are consumed more by richer households. For example, the richest decile spends 10 times more than the poorest decile on alcoholic beverages as a share of total spending, and these products have among the highest excise tax rates. However, indirect taxes are also poverty-increasing, with the US $\$ 1.25$-a-day poverty headcount rate increasing by 3.65 points as a result of these taxes (table 5).

Ethiopia's indirect taxes relative to GDP are average compared with other countries (as shown earlier in figure 1), but they make up a lower share of market income than in all other countries considered. While indirect taxes amount to 3 percent of disposable income of the poorest decile in Ethiopia, they amount to 18 percent of the disposable income of the poorest decile in Bolivia, and 11 percent in Brazil.

This highlights the challenge facing Ethiopia: even low and progressive taxes can make many poor households poorer and some nonpoor households poor. To the extent possible, taxes should be made more progressive to limit their impoverishing effect. It is perhaps unlikely that Ethiopia can reduce its reliance on indirect taxes or make them more progressive given how well it compares with middle-income countries on these fronts, but to the extent that direct taxes can be made more progressive, this should be considered. For example, the minimum income above which PIT is levied could be raised along with higher tax rates at the top, and

\footnotetext{
${ }^{13}$ We differentiate between formal and informal or self-employed workers, as further discussed in the appendix.
} 
agricultural income taxes can be made more progressive by encouraging a higher per hectare tax rate for households with larger landholdings.

\section{Social Spending}

As noted earlier, extreme poverty (measured by the US\$1.25-a-day PPP line) was higher for consumable income (after all taxes, direct transfers, and subsidies) than for market income (before taxes or transfers), as shown in table 3. In other words, so many poor and near-poor individuals are impoverished by taxes, particularly consumption taxes, that poverty ends up higher after fiscal interventions. Arguably, even if the poor are hurt in cash terms, these poverty-increasing taxes are funding the access of the poor to education and health benefits. Indeed, as seen in figure 3, final income shows that the poor benefited-and benefited relatively more than other income groups-from the in-kind transfers in primary education and health, even though the use of services is not universal and many of the poor are still excluded. The subsections below discuss the incidence of spending on direct transfers, indirect subsidies, and in-kind transfers for education and health services.

\section{Direct Transfers}

Direct transfers through the PSNP and food aid programs are progressive, equalizing, and propoor, with more than 58 percent of the benefits going to households below the national poverty line. ${ }^{14}$ PSNP transfers are more progressive and help to reduce inequality and poverty more than emergency food aid (table 5), in line with the findings of the broader literature on food aid targeting in Ethiopia and the results of PSNP external evaluations (Gilligan et al. 2010).

Food aid is targeted to communities particularly affected by disasters, and although there is often targeting of poor households within these communities, this is done in an ad hoc fashion to ensure aid is provided in a timely manner. As a result, targeting errors in the selection of individuals at the local level can be quite high. By comparison, the PSNP has clear targeting rules and identification of beneficiaries, resulting in lower targeting errors (Gilligan et al. 2010).

Beyond the fact that direct transfers are progressive and equalizing, PSNP and food aid transfers have a sizable direct effect on poverty, reducing it by 2 percentage points (table 5). The direct effect of these transfers was to reduce poverty rates from 33 percent to 31 percent (estimated by comparing consumption with and without the size of the transfer provided). Moreover, the transfers reduced the poverty gap by 1.4 percentage points (to 14.3 percent) and reduced the poverty severity (the poverty gap squared) by 0.9 percentage points (to 21.5

\footnotetext{
${ }^{14}$ Spending is considered "progressive" whenever the concentration coefficient is lower than the Gini for market income-meaning that the benefits from that spending as a share of market income tend to fall with market income. Spending is "pro-poor" whenever the concentration coefficient is not only lower than the Gini but also negative-that is, the share of spending going to the poor is higher than their population share. Pro-poor spending implies that the per capita government spending on the transfer tends to fall with market income.
} 
percent). Though small, the marginal contribution of cash transfers to poverty reduction is higher for Ethiopia than for Bolivia, El Salvador, and Guatemala.

In terms of generosity, direct transfers from the PSNP and food aid make up a smaller share of market income of the poorest deciles in Ethiopia than in middle-income countries such as Armenia, Argentina, South Africa, or Uruguay, suggesting there is room to increase the size of direct transfer programs, targeting them to more households. However, they do make up about 20 percent of the poorest decile's market income, which is somewhat comparable to the share of direct transfers in Mexico (31 percent) and more than the shares achieved in Indonesia and Peru (4 percent and 11 percent, respectively).

\section{Indirect Subsidies}

Poorer households consume less electricity, kerosene, and wheat than richer households, and as a result, none of these subsidies is pro-poor (figure 5). However, wheat and kerosene make up a larger share of spending among poorer households than among richer households, and consequently these two subsidies are progressive in relative terms, meaning that they make up a larger share of the incomes of the poor (figure 6). Importantly, they are also equalizing and poverty-reducing (as shown earlier in table 5). In contrast, electricity makes up a smaller share of spending among poorer households than among richer households; hence, electricity subsidies are regressive and unequalizing (figures 5 and 6 ).

Figure 5. Progressivity and Pro-Poorness of Public Spending in Ethiopia, 2011

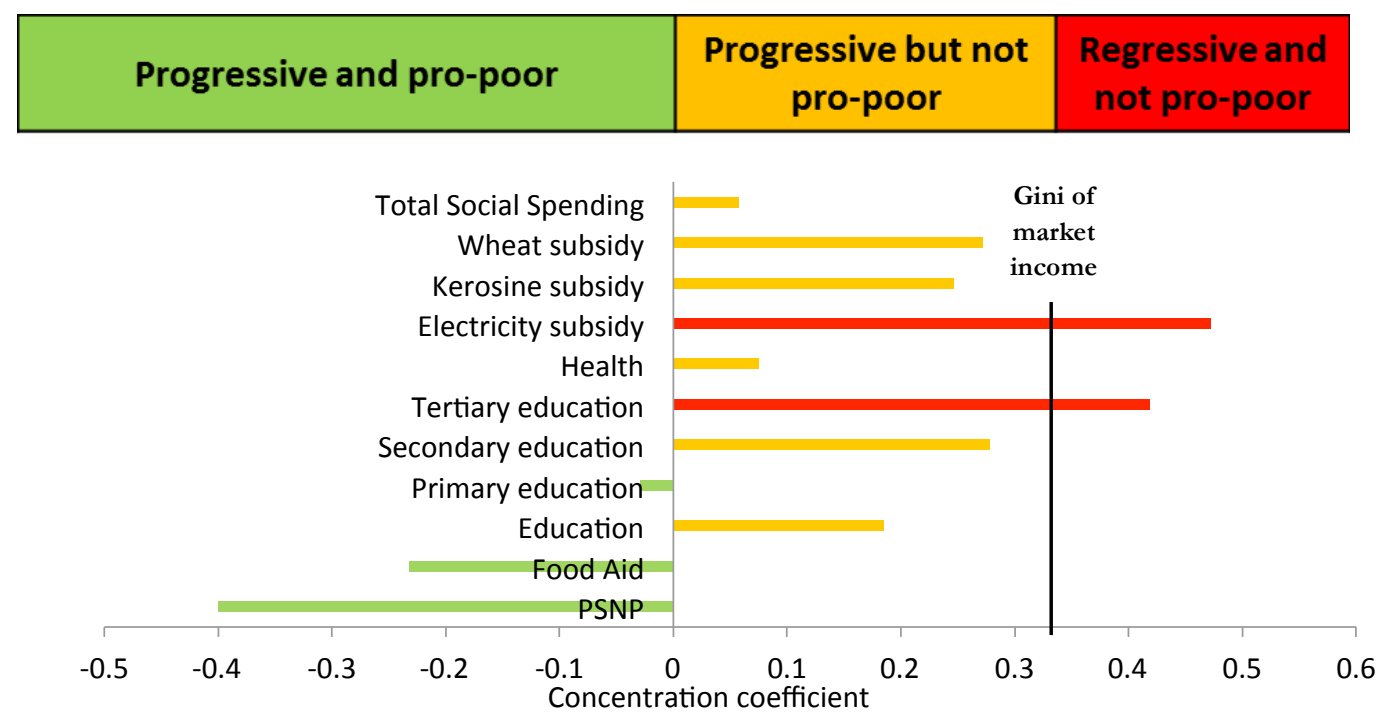

Source: Based on 2011 Household Consumption Expenditure Survey (HCES) and 2011 Welfare Monitoring Survey (WMS) data.

Note: PSNP = Productive Safety Net Program. Spending is "progressive" when the concentration coefficient is lower than the Gini coefficient for market income-meaning that the benefits from that spending, as a share of market income, tend to fall with market income. Spending is "pro-poor" when the concentration coefficient is not only lower than the Gini but also negative-implying that the per capita government spending on the transfer 
tends to fall with market income. (This case is also sometimes called progressive in absolute terms.) "Market income" comprises pretax wages, salaries, income earned from capital assets (rent, interest, or dividends), and private transfers. The Gini coefficient measures the equality of income distribution, ranging from zero (perfect equality) to one (maximal inequality).

\section{Figure 6. Concentration Curves for Indirect Subsidies in Ethiopia, 2011}

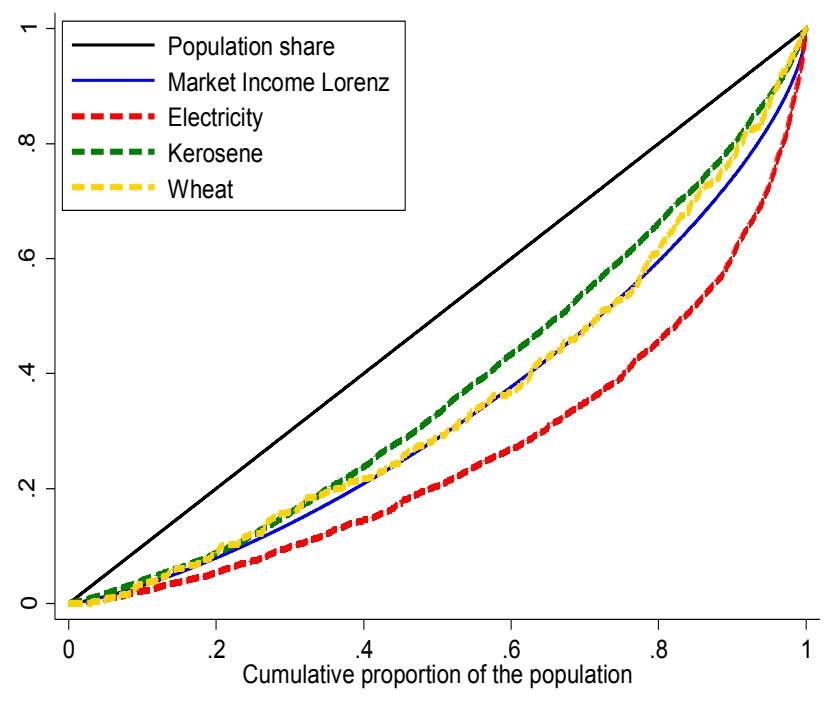

Source: Based on 2011 Household Consumption Expenditure Survey (HCES) data.

Note: "Market income" comprises pretax wages, salaries, income earned from capital assets (rent, interest, or dividends), and private transfers.

The richest 30 percent of the population received 65 percent of the electricity subsidies, while the poorest 30 percent-those living below the national poverty line-obtained only 10 percent of the electricity subsidies. Among the three subsidies (electricity, kerosene, and wheat), electricity is the largest. Care should be taken not to assume, however, that the removal of electricity subsidies would not hurt the poor. If not compensated in some other way, some of the poor, especially the urban poor, will become poorer if electricity subsidies are reduced.

\section{In-Kind Transfers}

In assessing how much education and health spending benefit the poor, we have to caution that our analysis does not address the quality of such spending. We use government expenditure data on the various forms of education and health services to estimate the unit costs of these programs. The analysis thus assumes that the actual benefit received by individuals is equal to the amount spent per capita. Because the quality of school infrastructure, teachers, and health clinics, and hospitals varies across the country, this is a clear limitation of the analysis. 


\section{Education}

The results show that spending on education is progressive in relative terms, but only primary education spending is pro-poor (figure 5). Half of public spending on education in 2011 was spent on tertiary education, of which a considerable amount was spent on building universities. Therefore, the analysis assumed that the benefits of investments in university buildings made in 2011 would be distributed over 10 years (see appendix). Given this assumption, spending on primary education makes up the largest share of education benefits delivered to households in 2011.

Figure 7 shows that spending on primary education as a proportion of market income is very high for poorer households: for those in the poorest decile, the value of primary education benefits received is 5.6 percent of market income compared with 0.5 percent for the richest decile. The absolute amount of primary education benefits received by poor households is also larger than those received by rich households (figure 7), and as a result primary education spending is pro-poor in addition to being progressive and equalizing (table 5).

Figure 7. Concentration Curves for Education Spending in Ethiopia, 2011

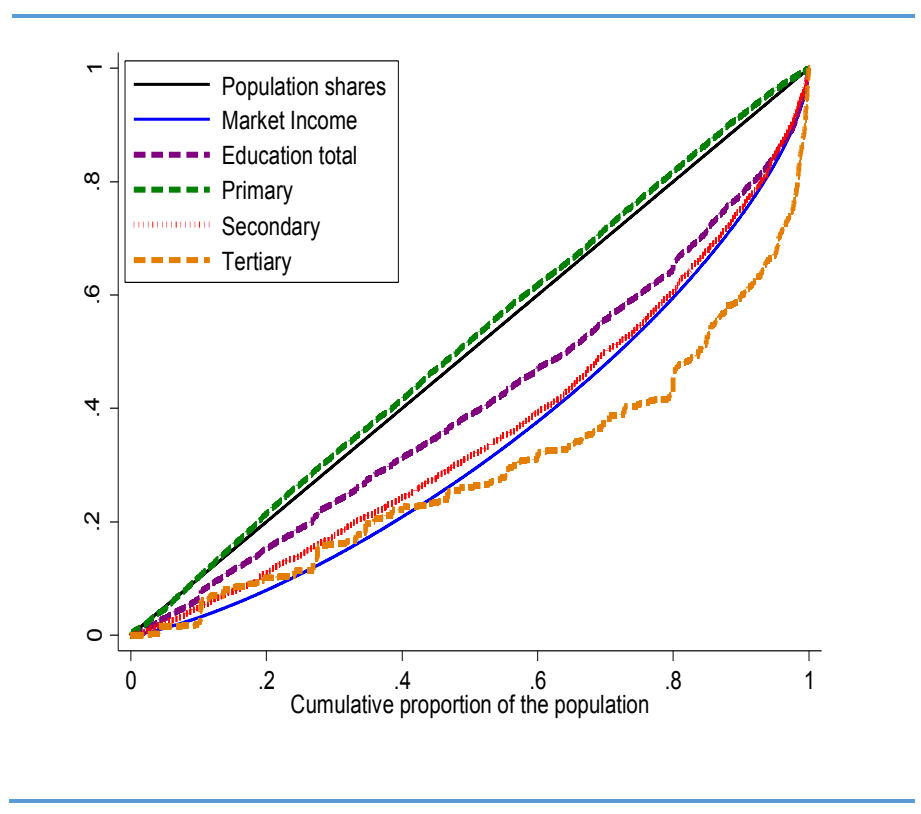

Source: Based on 2011 Household Consumption Expenditure Survey (HCES) data.

Note: "Market income" comprises pretax wages, salaries, income earned from capital assets (rent, interest, or dividends), and private transfers.

Secondary education spending is also progressive in relative terms and equalizing, making up a larger share of market income for poor households than for rich households, but it is not propoor: richer households receive a larger share of the secondary education spending (figure 7 , table 5). In contrast, spending on tertiary education is regressive and unequalizing. Forty percent of spending on tertiary education is received by students in the richest decile, while 
only 2.5 percent of spending is received by the poorest decile. However, spending on tertiary education has beneficial impacts on long-term economic growth rates through technology absorption and innovation, as well as through service delivery (for example, through graduation numbers of new primary school teachers) and should not be reduced; rather, a focus on increased access for poorer families is needed.

Low enrollment rates in secondary and tertiary education limit the progressivity of spending on nonprimary education. Primary education is available in almost all villages in Ethiopia, resulting in high enrollment (reaching 96 percent in 2013), but dropout rates are high and primary completion is very low. This in turn causes secondary school enrollment rates to fall well below those of comparable countries. Children from poorer backgrounds make slower progress through school and are more likely to drop out without completing primary school. They are thus less likely to enroll in secondary school. It is the opportunity cost of being in school - a need for the child to work to contribute to the family's well-being - that is the main problem (Chaudhury et al. 2006; Weir 2011; Woldehanna et al. 2011). A quarter of total secondary education spending benefits the richest decile, compared with only 5 percent that benefits the poorest decile. Completion of secondary school is a prerequisite for tertiary enrollment, so inequalities in secondary school enrollment are also reflected in tertiary enrollment, despite stipends for attendance available to all households.

The pattern in Ethiopia is not uncommon for low-income countries. As countries become richer, and educational coverage increases at all levels, education spending becomes more progressive. That is, while the average incidence may not be as progressive as in middleincome countries, the marginal incidence is usually increasingly progressive and more equalizing.

\section{Health}

Health expenditures are equalizing (table 5). Health benefits received by the poorest households are relatively high as a share of their market incomes (figure 8). However, these expenditures are not pro-poor: about 9 percent of health spending is concentrated in the poorest decile, while 14 percent is concentrated in the richest decile (figure 5). Nevertheless, this inequality in the concentration of spending is not as large as in other countries such as Indonesia ( 7 percent for the poorest, 15 percent for the richest) or Peru ( 6 percent for the poorest, 15 percent for the richest). 
Figure 8. Health Spending Concentration and Incidence, by Income Decile, in Ethiopia, 2011

\section{a. Health benefit concentration curve}

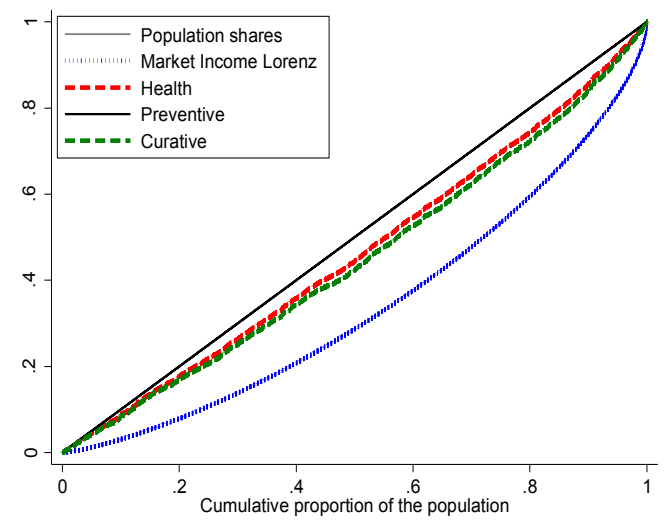

\section{b. Health benefit incidence}

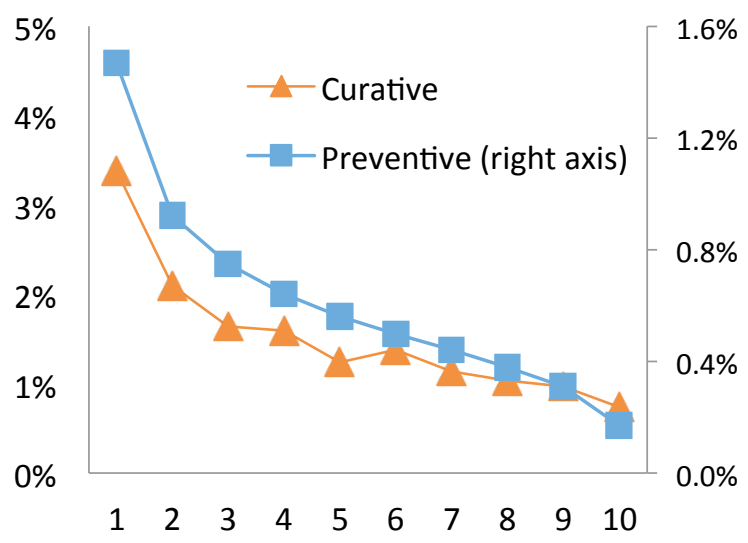

Source: Based on 2011 Household Consumption Expenditure Survey (HCES) and 2011 Welfare Monitoring Survey (WMS) data.

Note: "Market income" comprises pretax wages, salaries, income earned from capital assets (rent, interest, or dividends), and private transfers.

Health extension agents are present in all neighborhoods (kebeles) and ensure that a basic range of health services are readily available to all households. This ensures that preventive health care spending — which is about 27 percent of overall health spending-is progressive in relative terms. However, curative health care is less progressive. Although preventive health care services are provided for free, marginal user fees are usually charged for curative public health services, which are much lower than the cost of service. To protect the poor against the financial burden of user fees, there are fee waiver and exemption systems at public health centers and hospitals. However, poorer households do not avail themselves of curative health services to the same extent, resulting in less-progressive public spending relative to preventive services (figure 8 , panel b).

\section{Overall Incidence of Public Spending}

Overall, the progressive nature of taxes in Ethiopia is complemented by progressive social spending, but less than half of the spending analyzed is pro-poor. Of the total social spending included in the study, 81 percent is progressive and equalizing (only 44 percent is progressive and pro-poor), and 19 percent of spending is regressive and unequalizing.

The concentration coefficients (figure 5) show that PSNP, food aid, and primary education are the most progressive and pro-poor spending categories. Secondary school, health, wheat and kerosene subsidies, and overall education spending are neutral (that is, their distribution is almost identical to the distribution of market income). Spending on tertiary education and on electricity subsidies is regressive and unequalizing. The regressivity of tertiary education might 
be associated with low completion rates of primary and secondary education, which implies that a lower share of population may attend tertiary education. The budget allocated to tertiary education is higher than the budget allocated to upper-secondary education, so this result is likely to persist as long as primary and secondary completion rates do not improve. It is important to note that, in general, spending on tertiary education is not regressive in lowincome countries. Of 13 low- and middle-income countries analyzed by Lustig (2015), spending on tertiary education around 2010 was unequalizing only in Ethiopia, Guatemala, and Indonesia.

Moving resources from off-budget subsidies (included in this analysis) to direct transfer programs targeted to the poor would improve the progressivity of public spending. If all subsidy financing were used instead to provide transfers to poor households with the same targeting effectiveness as the PSNP, this would further reduce the poverty headcount (at the national poverty line) by 2 percentage points. It would also reduce the poverty gap by 5 percentage points and poverty severity by 12.5 percentage points. Olinto and Sherpa (2014) discuss how a transfer program of 0.2 percent targeted to poorest households in Addis Ababa could cut the city's current poverty rate in half. This is the same as the cost of electricity subsidies to the richest 40 percent.

\section{Conclusion}

Fiscal policy in Ethiopia reduces inequality and lowers the depth and severity of poverty but increases the incidence of poverty. Poor households are net beneficiaries of fiscal policy when education and health transfers are taken into account. However, in terms of purchasing power, poor households pay taxes_-both direct and indirect-and the transfers and benefits they receive do not compensate all households for the taxes they have paid. As a result, although the depth and severity of poverty fall as a result of fiscal policy, 1 in 4 households are impoverished (either made poor or poorer) after direct taxes are paid and transfers received, and nearly 1 in 10 households are impoverished after all taxes are paid and benefits received (including public spending on education and health).

The analysis in this paper highlights two areas in which Ethiopia could mitigate the negative impact of taxes and indirect subsidies: (a) by reducing the incidence of direct taxes among the bottom deciles while increasing the progressivity of direct taxes, particularly PIT and agricultural taxes; and (b) by redirecting subsidy spending to direct transfers benefiting the poorest.

In Ethiopia, taxes are progressive and equalizing, but their progressivity could be further enhanced. In terms of direct taxes, in addition to personal income taxes, households also pay direct taxes in the form of agricultural and land taxes, particularly households in the bottom deciles. This is particularly costly to the poor in Ethiopia because its bottom deciles are much poorer than in other countries. 
Moreover, indirect taxes place a burden on the poor-despite their progressivity-because so many households are poor in Ethiopia, and these taxes are generally levied equally regardless of income level. Although indirect taxes are not regressive, there is a clear trade-off between greater equity and efficiency if the government were to try to collect more direct taxes to improve equity.

On the expenditure side, direct transfers are progressive, pro-poor, and have been effective in reducing poverty and inequality. In contrast, although indirect subsidies are meant to benefit the poor, the top deciles benefit the most from subsidy spending. The electricity subsidy, in particular, is highly regressive and unequalizing, because access to electricity requires an investment that many of the poor cannot afford.

Given the effectiveness of the PSNP, Ethiopia could further reduce poverty if the spending on indirect subsidies were shifted to direct transfers benefiting the poor. As noted earlier, if all subsidy financing were instead used to provide transfers to poor households at the same level of effectiveness as the PSNP's, the population living below the national poverty line would decrease by 2 percentage points. Such a change would also reduce the poverty gap by 5 percentage points and poverty severity by 12.5 percentage points. However, this shift to direct transfers would need to ensure that poor people currently receiving electricity subsidies also get compensated, because the subsidies make up a larger share of their incomes (particularly the urban poor with access to electricity).

Though overall spending on education and health is progressive and equalizing, it is not propoor because of limited utilization by the poor of secondary and tertiary education services. Similarly, there is a limited use of curative health services by the poor. Much progress has been made in increasing coverage of education and health services in recent years, and more progress is needed to further benefit the poor and improve progressivity. 


\section{References}

Afkar, Rythia, Jon Jellema and Matthew Wai-Poi. 2017. "The Distributional Impact of Fiscal Policy in Indonesia," in The Distributional Impact of Fiscal Policy: Experience from Developing Countries, edited by Gabriela Inchauste and Nora Lustig. Washington DC: World Bank.

Beneke, Margarita, Nora Lustig, and Jose Andres Oliva. 2018. "The Impact of Taxes and Social Spending on Inequality and Poverty in El Salvador." Chapter 15 in Commitment to Equity Handbook. Estimating the Impact of Fiscal Policy on Inequality and Poverty, edited by Nora Lustig (Brookings Institution Press and CEQ Institute, Tulane University). Advance online version available at http://www.commitmentoequity.org/publications/handbook.php.

Besley, Timothy, and Torsten Persson. 2009. "The Origins of State Capacity: Property Rights, Taxation, and Politics." The American Economic Review 99 (4):1218-44.

Bucheli, Marisa, Nora Lustig, Maximo Rossi, and Florencia Amabile. 2014. "Social Spending, Taxes and Income Redistribution in Uruguay." The Redistributive Impact of Taxes and Social Spending in Latin America. Special Issue, Public Finance Review 42 (3):413-433. doi: http://dx.doi.org/10.1177\%2F1091142113493493.

Cabrera, Maynor, Nora Lustig, and Hilcias Moran. 2014. "Fiscal Policy, Inequality and the Ethnic Divide in Guatemala." CEQ Working Paper 20. Center for Inter-American Policy and Research and Department of Economics, Tulane University and InterAmerican Dialogue, October.

Central Statistical Agency, 2010/11 Household Consumption Expenditure Survey, Analytical Report, (Addis Ababa, 2012).

Central Statistical Agency, 2010/11 Household Consumption Expenditure Survey, Socio-economic monitoring survey, (Addis Ababa, 2012).

Chaudhury, Nazmul, Jeffrey Hammer, Michael Kremer, Karthik Muralidharan, and F. Halsey Rogers. 2006. "Missing in Action: Teacher and Health Worker Absence in Developing Countries." Journal of Economic Perspectives 20 (1):91-116.

Duclos, Jean-Yves, and Martin Tabi. 1996. "The Measurement of Progressivity, with an Application to Canada." The Canadian Journal of Economics 1 (Special Issue: Part 1): S165-S170.

Ethiopian Revenues and Customs Authority, Proclomation No. 307/2002 Excise Tax Proclamation, (Addis Ababa, 2002).

Foster, J., J. Greer, and E. Thorbecke. 1984. "A Class of Decomposable Poverty Measures.” Econometrica 3 (52):761-766. 
Fullerton, D., and G. Metcalf. 2002. “Tax Incidence.” In Handbook of Public Economics Volume 4, edited by A. Auerbach and M. Feldstein, 1787-1872. Amsterdam: Elsevier Science.

Gilligan, D., J. Hoddinott, N. Kumar, and A. Taffesse. 2010. "Targeting Food Security Interventions When 'Everyone Is Poor': The Case of Ethiopia's Productive Safety Net Programme." Ethiopia Strategy Support Program (ESSP) Working Paper 24. International Food Policy Research Institute (IFPRI), Washington, DC.

Higgins, Sean, and Nora Lustig. 2016. "Can a Poverty-reducing and Progressive Tax and Transfer System Hurt the Poor?" Journal of Development Economics 122 (September):6375. doi: 10.1016/j.jdeveco.2016.04.001.

Higgins, Sean, and Claudiney Pereira. 2014. "The Effects of Brazil's Taxation and Social Spending on the Distribution of Household Income." The Redistributive Impact of Taxes and Social Spending in Latin America. Special Issue, Public Finance Review 42 (3):346-367. doi: $10.1177 / 1091142113501714$.

Inchauste, Gabriela and Nora Lustig. 2017. "Overview: Fiscal Policy and Redistribution." In The Distributional Impact of Fiscal Policy: Experience from Developing Countries, edited by Gabriela Inchauste and Nora Lustig. Washignton DC: World Bank.

Inchauste, Gabriela, Nora Lustig, Mashekwa Maboshe, Catriona Purfield, Ingrid Woolard and Precious Zikhali. 2017. "The Distributional Impact of Fiscal Policy in South Africa," in The Distributional Impact of Fiscal Policy: Experience from Developing Countries, edited by Gabriela Inchauste and Nora Lustig. Washington DC: World Bank.

Jaramillo Baanante, Miguel. 2014. "The Incidence of Social Spending and Taxes in Peru." The Redistributive Impact of Taxes and Social Spending in Latin America. Special Issue, Public Finance Review 42 (3):391-412. doi: 10.1177/1091142113496134.

Kakwani, Nanak C. 1977. "Measurement of Tax Progressivity: An International Comparison." The Economic Journal 87 (345):71-80.

Lambert, Peter. 2002. The Distribution and Redistribution of Income. 3rd ed. Manchester, U.K.: Manchester University Press.

Lustig, Nora. 2015. "The Redistributive Impact of Government Spending on Education and Health: Evidence from 13 Developing Countries in the Commitment to Equity Project." In Inequality and Fiscal Policy, edited by Sanjeev Gupta, Michael Keen, Benedict J. Clements and Ruud A. de Mooij. Washington, D.C.: International Monetary Fund.

Lustig, Nora, ed. 2018. Commitment to Equity Handbook. Estimating the Impact of Fiscal Policy on Inequality and Poverty. (Brookings Institution Press and CEQ Institute, Tulane University). Advance online version available at http://www.commitmentoequity.org/publications/handbook.php. 
Lustig, Nora, and Sean Higgins. 2013. "Commitment to Equity Assessment (CEQ): Estimating the Incidence of Social Spending, Subsidies and Taxes. Handbook." CEQ Working Paper 1. Center for Inter-American Policy and Research and Department of Economics, Tulane University and Inter-American Dialogue, September.

MoFED (Ministry of Finance and Economic Development), Growth and Transformation Plan 2010/11-2014/15, National planning document, MoFED, (Addis Ababa, 2010), http://www.mofed.gov.et/web/guest/-/gtp-main-document-vol1 ? inheritRedirect $=$ true.

NPC (National Planning Commission), Growth and Transformation Plan II (GTP II) (2015/162019/20), National planning document, NPC, (Addis Ababa, 2016).

Olinto, P., and M. Sherpa. 2014. "Targeting Assessment and Ex-Ante Impact Simulations of Addis Ababa Safety Net." Background paper for the Ethiopia Poverty Assessment. World Bank, Washington, DC.

Paz Arauco, Veronica, George Gray-Molina, Wilson Jimenez, and Ernesto Yanez. 2014. "Explaining Low Redistributive Impact in Bolivia." The Redistributive Impact of Taxes and Social Spending in Latin America. Special Issue, Public Finance Review 42 (3):326-345. doi: 10.1177/1091142113496133.

Sauma, Pablo, and Juan Diego Trejos. 2014. "Social Public Spending, Taxes, Redistribution of Income, and Poverty in Costa Rica." CEQ Working Paper 18. Center for InterAmerican Policy and Research and Department of Economics, Tulane University and Inter-American Dialogue, March.

Scott, John. 2014. "Redistributive Impact and Efficiency of Mexico’s Fiscal System." The Redistributive Impact of Taxes and Social Spending in Latin America Special Issue, Public Finance Review 42 (3):368-390. doi: 10.1177/1091142113497394.

Weir, Sharada. 2011. "Parental Attitudes and Demand for Schooling in Ethiopia." Journal of African Economies 20 (1):90-110.

Woldehanna, Tassew, Retta Gudisa, Yisak Tafere, and Alula Pankhurst. 2011. "Understanding Changes in the Lives of Poor Children: Initial Findings from Ethiopia.” Round 3 Survey Report for Young Lives: An International Study of Child Poverty, U.K. Department of International Development (DFID), University of Oxford.

World Bank. 2003. “A User's Guide to Poverty and Social Impact Analysis." Reference document. World Bank, Washington, DC.

. 2013. "The Federal Democratic Republic of Ethiopia, Ethiopian Electric Power Corporation, Report on Accountability Issues." Unpublished report. World Bank, Washington, DC. 
—. 2015. “Ethiopia Poverty Assessment 2014.” Report No. AUS6744. World Bank, Washington, DC.

- 2016. Poverty and Shared Prosperity 2016: Taking on Inequality. Washington, DC: World Bank.

Younger, Stephen D. and Artsvi Khachatryan. 2017. "Fiscal Incidence in Armenia," in The Distributional Impact of Fiscal Policy: Experience from Developing Countries, edited by Gabriela Inchauste and Nora Lustig. Washington DC: World Bank. 


\section{Appendix: Methodological Assumptions}

\section{Direct Taxes}

To estimate household-level personal income tax, the income tax schedule was applied on the disposable income of urban individuals who were employed by formal private or public organizations (table A.1, panel a). Rural individuals were assumed not to be formally employed. For self-employed individuals and those employed in the informal sector, we applied the business tax schedule to determine personal income tax (table A.1, panel b). Tax evasions (calculated as the difference between total actual tax collected and tax estimated based on income) are assumed to be borne by all self-employed and employees of the informal sector in proportion to income.

Table A.1 Direct Tax Rate Schedules in Ethiopia, 2011

a. Personal or employment income ${ }^{a}$

\begin{tabular}{|c|c|c|c|c|c|}
\hline $\begin{array}{l}\text { Income bracket } \\
\text { (Br per month) }\end{array}$ & $\begin{array}{c}\text { Tax rate } \\
(\%)\end{array}$ & $\begin{array}{c}\text { Standard } \\
\text { deduction } \\
(\mathrm{Br})\end{array}$ & $\begin{array}{l}\text { Business income or } \\
\text { net profit bracket } \\
\text { (Br per year) }\end{array}$ & $\begin{array}{c}\text { Tax rate } \\
(\%)\end{array}$ & $\begin{array}{l}\text { Deduction } \\
\text { (Br) }\end{array}$ \\
\hline 0-150 & Exempted & n.a. & $0-1,800$ & Exempted & n.a. \\
\hline $151-650$ & 10 & 15.0 & $1,801-7,800$ & 10 & 180 \\
\hline $651-1,400$ & 15 & 47.5 & $7,801-16,800$ & 15 & 570 \\
\hline $1,401-2,350$ & 20 & 117.5 & $16,801-28,200$ & 20 & 1,410 \\
\hline $2,351-3,550$ & 25 & 235.0 & $28,201-42,600$ & 25 & 2,520 \\
\hline $3,551-5,000$ & 30 & 412.5 & $42,601-60,000$ & 30 & 4,950 \\
\hline Over 5,000 & 35 & 662.0 & Over 60,000 & 35 & 7,950 \\
\hline
\end{tabular}

Source: Ministry of Finance and Economic Development.

Note: $\mathrm{Br}=$ birr. n.a. $=$ not applicable.

a. The analysis applied this tax schedule to calculate the personal income tax of urban individuals employed by formal private or public organizations.

b. The analysis applied this tax schedule to calculate the personal income tax on self-employed and informally employed individuals.

Agricultural income taxes and rural land used fees are, for the most part, calculated on the basis of landholding size. The tax schedule for this tax and fee is set by regional and local governments and, as such, varies from locale to locale. However, many of the main tax schedules were examined and found to levy similar per hectare tax rates regardless of land size. An example for Oromia region suggests that, if anything, the per hectare tax rate generally falls with landholding size (table A.2). 
Table A.2 Land Use Fee and Agricultural Income Tax Schedule in Oromia Regional State, Ethiopia, 2011

\begin{tabular}{|c|c|c|c|c|}
\hline $\begin{array}{c}\text { Land size } \\
\text { (hectare) }\end{array}$ & $\begin{array}{c}\text { Rural land use } \\
\text { fee (Br) }\end{array}$ & $\begin{array}{c}\text { Income tax } \\
\mathbf{( B r})\end{array}$ & $\begin{array}{c}\text { Total } \\
\mathbf{( B r})\end{array}$ & $\begin{array}{c}\text { Average tax rate } \\
\text { (Br per hectare) }\end{array}$ \\
\hline$<0.5$ & 15 & Exempted & 15 & 40.0 \\
\hline $0.5-1$ & 20 & 20 & 40 & 53.3 \\
\hline $1-2$ & 30 & 35 & 65 & 43.3 \\
\hline $2-3$ & 45 & 55 & 100 & 40.0 \\
\hline $3-4$ & 65 & 70 & 135 & 38.6 \\
\hline $4-5$ & 90 & 100 & 190 & 42.2 \\
\hline$>5$ & 120 & 140 & 260 & 34.7 \\
\hline
\end{tabular}

Source: World Bank calculations; Oromia Regional State, Proclamation to Amend Rural Land Use Payment and Agricultural Income Tax (No. 131/2007).

Note: $\mathrm{Br}=$ birr.

To estimate agricultural tax and land use fees, we assumed that the rates are always constant per hectare. The landholding size was collected in the 2011 Household Consumption Expenditure Survey (HCES), but standardized units were often not recorded, making the HCES impossible to use. For this reason, the Ethiopian Rural Socio-Economic Survey (ERSS) was used to define the association between land size and consumption in each region, which was then used to impute a land size for each household in the HCES. A region's total tax revenue was divided by total agricultural landholdings in the region to generate an average tax rate per hectare. This rate was used with the imputed land size to estimate the amount of agricultural tax paid by each household. This method implicitly assumes that the average tax rate per hectare is constant across farm size. An example from Oromia (table A.2) suggests this is a reasonable assumption. If anything, in Oromia average tax rates decrease with land size which suggests that the regressivity of agricultural taxes might be underestimated in Oromia.

\section{Indirect Taxes}

Indirect taxes are estimated by price multiplier analysis using the social accounting matrix (SAM) developed in 2006 by the Ethiopian Development Research Institute (EDRI). The SAM has 93 commodity accounts and distinguishes between purchased and own-consumed commodities (77 are purchased, and 16 are own-consumed commodities). The indirect tax account corresponding to each good or service in the SAM represents the actual indirect tax collected. This means that the ratio of the indirect tax to the total supply value of each commodity represents the effective tax rate of each product. For own-consumed commodities, there is no indirect tax in the SAM because the actually collected tax from such commodities is zero. 
The second-round effects of indirect taxes are the price burden on consumers resulting from indirect taxes paid for inputs used in the production process. The input-output table is used to calculate the effect of taxes on intermediate inputs on prices of final goods and services. The overall effect is the sum of the direct and indirect effect of indirect taxes. The overall effect of indirect taxes on prices of commodities from the input-output table is simulated, using the World Bank's SimSIP Poverty simulator, ${ }^{15}$ to estimate the burden of indirect taxes for each product (as a percentage of the value of supply) in the commodity account. Using item-level consumption in the HCES data, we estimated the price burden on each household based on the proportional increase in the price of each good or service and the household's expenditure on corresponding goods and services, which is assumed to be borne entirely by the consumers.

One concern is informality and the potential evasion of consumption taxes. It is impossible to know from the survey whether a household has made a purchase from a shop that pays VAT or not. Further, in a standard competitive model, prices at shops that do not pay VAT would be the same as those at VAT-paying shops, with the benefits of nonpayment going to the firm owner rather than to the government. Households suffer the incidence of the tax regardless of the tax status of the seller, though not all the benefits go to the fiscal authorities. In essence, we assume that all households buy the same share of taxable goods so that the effects of tax avoidance or evasion on market prices are spread across the population in proportion to each household's expenditures.

A sensitivity analysis uses an alternative way of estimating the impact of indirect taxes. The benchmark estimate included both the first- and second-round effects of all types of indirect taxes (including VAT). This approach considers VAT to be similar to sales tax in which additional taxes are paid in each link of the transaction chain. The alternative approach estimated only the first effect of VAT on prices because, in principle, producers and retailers are entitled to a refund of the VAT payments for input purchases, making intermediate inputs tax-free. The only exception to this concerns items that are VAT-exempt, which would have some indirect impact of VAT on intermediate goods because, if a good is VAT-exempt, producers are not entitled to a VAT refund for the inputs used in producing the item. As a result, in the sensitivity analysis, the first-round effect of VAT is estimated for items on which VAT is levied, and then only the second-round effects are included for goods and services that are VAT-exempt.

Because the sensitivity analysis excludes the second-round effects of VAT on most items, the estimate of indirect tax burden using this method is slightly smaller than the estimate in the benchmark estimate. As a result, the associated income measures of consumable income and final income become slightly higher in the sensitivity analysis. Apart from the slight change in level, the pattern of incidence of indirect taxes on the different income groups based on this method is similar to the pattern in the benchmark estimate. Thus the overall storyline of the

\footnotetext{
${ }^{15}$ For more information on the simulator, see the "SimSIP Poverty" summary sheet in World Bank $(2003,70)$.
} 
relative burden of indirect taxes on different income groups does not change whichever method is used.

Table A.3 Locally Produced or Imported Goods Subject to Excise Tax in Ethiopia

\begin{tabular}{|c|c|c|}
\hline $\begin{array}{l}\text { Ser. } \\
\text { No. }\end{array}$ & Type of Product & $\begin{array}{l}\text { Excise tax } \\
\text { rate }(\%)\end{array}$ \\
\hline 1 & Any type of sugar (in solid form) excluding molasses & 33 \\
\hline 2 & Drinks & \\
\hline 2.1 & All types of soft drinks (except fruit juices) & 40 \\
\hline 2.2 & Powder soft drinks & 40 \\
\hline 2.3 & Water bottled or canned in a factory & 30 \\
\hline 2.4 & Alcoholic Drinks & \\
\hline 2.4 .1 & All types of beer \& stout & 50 \\
\hline 2.4 .2 & All types of wine & 50 \\
\hline 2.4 .3 & Whisky & 50 \\
\hline 2.4.4 & Other alcoholic drinks & 100 \\
\hline 3 & All types of pure Alcohol & 75 \\
\hline 4 & Tobacco \& Tobacco Products & \\
\hline 4.1 & Tobacco Leaf & 20 \\
\hline 4.2 & Cigarettes, cigar, cigarillos, pipe tobacco, snuff and other tobacco products & 75 \\
\hline 5 & Salt & 30 \\
\hline 6 & Fuel-Super Benzene, Regular Benzene, Petrol, Gasoline and other Motor Spirits & 30 \\
\hline 7 & Perfumes and Toilet Waters & 100 \\
\hline 8 & Textile and textile products & \\
\hline 8.1 & $\begin{array}{l}\text { Textile fabrics, knitted or woven, of natural silk, rayon, nylon, wool or other } \\
\text { similar materials }\end{array}$ & 10 \\
\hline 8.2 & $\begin{array}{l}\text { Textile of any type partly or wholly made from cotton, which is grey, white, } \\
\text { dyed or printed, in pieces of any length or width (except Mosquito net and } \\
\text { "Abudgedid") and including, blankets, bedsheets, counterpanes, towels, table } \\
\text { clothes and similar articles }\end{array}$ & 10 \\
\hline 8.3 & Garments & $\frac{10}{20}$ \\
\hline $\begin{array}{ll}9 \\
10\end{array}$ & $\begin{array}{l}\text { Personal adornment made of gold, silver or other materials } \\
\text { Dish washing machines of a kind for domestic use }\end{array}$ & $\frac{20}{80}$ \\
\hline 11 & Washing machines of a kind for domestic purposes & 30 \\
\hline 12 & Video decks & 40 \\
\hline 13 & Television and Video Cameras & 40 \\
\hline 14 & $\begin{array}{l}\text { Television broadcast receivers whether or not combined with gramophone, } \\
\text { radio, or sound receivers and reproducers }\end{array}$ & 10 \\
\hline 15 & $\begin{array}{l}\text { Motor passenger cars, Station Wagons, utility cars, and Land Rovers, Jeeps } \\
\text { pickups, similar vehicles (including motorized caravans), whether assembled, } \\
\text { together with their appropriate initial equipment }\end{array}$ & \\
\hline 15.1 & Up to 1,300 c.c. & 30 \\
\hline 15.2 & From 1,301 c.c. up to 1800 c.c. & 60 \\
\hline 15.3 & Above 1,800 c.c. & 100 \\
\hline 16 & Carpets & 30 \\
\hline 17 & Asbestos and Asbestos Products & 20 \\
\hline 18 & Clocks and watches & 20 \\
\hline 19 & Dolls and toys & 20 \\
\hline
\end{tabular}


Source: Proclamation No. 307/2002, Excise Tax Proclamation, Ethiopian Revenues and Customs Authority.

Note: c.c. $=$ cubic centimeters (engine size).

\section{Direct Transfers}

The 2010/11 HCES identifies households that received payment from the Productive Safety Net Program (PSNP) and households that receive food aid. Both PSNP payments and food aid payments were based on household size, and so the beneficiary status of the households and the household size was used in conjunction with government PSNP and food aid expenditures to impute the value of transfers received by each household. We assume that food aid and PSNP transfers were distributed to all beneficiaries equally.

\section{Indirect Subsidies}

Item-level HCES data were used to estimate the amount of households' consumption of wheat, kerosene, and electricity. The subsidy per kilogram, liter, and kilowatt-hour for each good, respectively, was then applied to estimate the total value of the subsidy received by the household.

The wheat subsidy (Br 150 per quintal) was available only to households in the Addis Ababa city administration and so was only applied to households living in Addis Ababa. The electricity subsidy depends on the amount of electricity consumed (table A.4). The tariff rate is progressive, but the rates in all ranges are below the unsubsidized tariff. Petroleum prices are regulated by the government, and kerosene was subsidized at $\mathrm{Br} 2.17$ per liter.

\section{Table A.4 Tariff and Subsidy for Household Electricity Consumption in Ethiopia}

\begin{tabular}{|c|c|c|c|c|}
\hline \multicolumn{2}{|c|}{$\begin{array}{c}\text { Monthly } \\
\text { consumption }\end{array}$} & \multirow[b]{2}{*}{$\begin{array}{c}\text { Tariff } \\
(\mathrm{Br} / \mathrm{kWh} / \mathrm{mo.})\end{array}$} & \multirow{2}{*}{$\begin{array}{c}\text { Tariff without } \\
\text { subsidy } \\
\text { (Br/kWh/mo.) }\end{array}$} & \multirow[b]{2}{*}{$\begin{array}{c}\text { Subsidy } \\
\text { (Br/kWh/mo.) }\end{array}$} \\
\hline $\begin{array}{l}\text { From } \\
(\mathrm{kWh})\end{array}$ & $\begin{array}{c}\text { To } \\
(\mathbf{k W h})\end{array}$ & & & \\
\hline 0 & 50 & 0.273 & 0.967 & 0.694 \\
\hline 51 & 100 & 0.356 & 0.967 & 0.611 \\
\hline 101 & 200 & 0.499 & 0.967 & 0.468 \\
\hline 201 & 300 & 0.550 & 0.967 & 0.417 \\
\hline 301 & 400 & 0.567 & 0.967 & 0.401 \\
\hline 401 & 500 & 0.588 & 0.967 & 0.379 \\
\hline 501 & $1,000,000$ & 0.694 & 0.967 & 0.273 \\
\hline
\end{tabular}

Source: World Bank 2013.

Note: $\mathrm{kWh}=$ kilowatt-hours. 


\section{In-Kind Transfers}

\section{Education}

The Welfare Monitoring Survey (WMS) is used to determine the total number of students enrolled in primary, secondary, and tertiary education in each region. The unit costs of primary, secondary, and tertiary education were obtained by dividing the total regional public spending (from the Ministry of Finance and Economic Development's [MoFED] 2013 Government Finance Report) by total regional enrollment.

The monetized value of the in-kind education transfer at the household level is determined by multiplying the number of children enrolled in primary, secondary, and tertiary education in 2010/11 by the unit costs. Public education spending includes salary, wages, and operational costs as well as the administration and capital expenditure for primary and secondary education. For tertiary education, a significant proportion of capital expenditure (amounting to 1.6 percent of GDP) is excluded because there were large expenditures in expansion of higher education infrastructure that will serve another generation in the future. Only 10 percent of the capital expenditure is considered in the analysis to account for the benefits the current students are receiving.

\section{Health}

For health, total public health spending (from MoFED's 2013 Government Finance Report) is distributed to all individuals who received public health services as recorded in the WMS. For curative health services, in-kind health benefits are estimated in proportion to households' expenditure on public health fees. For households exempted from user fees, the average benefit is assumed. The WMS is used to identify households that received free health services. For preventive health services, the benefits are distributed to all households equally. Based on the budgets for different health programs, the proportion of preventive and curative health services is estimated to be 27 percent and 73 percent, respectively, of the total government health budget. 